\title{
Cyclization of peptides with two chemical bridges affords large scaffold diversities
}

Sangram S. Kale ${ }^{1,2}$, Camille Villequey ${ }^{1,2}$, Xu-Dong Kong ${ }^{1,2}$, Alessandro Zorzi ${ }^{1}$, Kaycie Deyle ${ }^{1}$ and Christian Heinis ${ }^{1}$

${ }^{1}$ Institute of Chemical Sciences and Engineering, Ecole Polytechnique Fédérale de Lausanne (EPFL), CH-1015 Lausanne, Switzerland

${ }^{2}$ The authors contributed equally to this work.

Correspondence should be addressed to C.H. E-mail: christian.heinis@epfl.ch

Keywords: macrocycle, cyclic peptide, scaffold diversity, macrocycle library, plasma kallikrein, IL17 
Successful screening campaigns depend on large and structurally diverse collections of compounds. In macrocycle screening, variation of the molecular scaffold is important for structural diversity, but to date it is challenging to diversify this aspect in large combinatorial libraries. Herein, we report the cyclization of peptides with two chemical bridges to provide rapid access to thousands of different macrocyclic scaffolds in libraries that are easy to synthesize, screen, and decode. Application of this strategy to phageencoded libraries allowed for the screening of an unprecedented structural diversity of macrocycles against plasma kallikrein, important in the swelling disorder hereditary angioedema. These libraries yielded inhibitors with remarkable binding properties (sub-nM $K_{\mathrm{i}},>$ 1,000-fold selectivity) despite the small molecular mass ( $\left.1200 \mathrm{Da}\right)$. An interlaced bridge format characteristic of this strategy provided a high proteolytic stability ( $t_{1 / 2}$ in plasma $>\mathbf{3}$ days), making double-bridged peptides potentially amenable to topical or oral delivery.

\section{INTRODUCTION}

Macrocycles have emerged as an interesting therapeutic class because they can bind to challenging targets that are not easily accessible to traditional small molecule compounds ${ }^{1,2}$. They owe their favorable binding properties to a larger size that enables interactions with extended surfaces where small molecules cannot normally bind and a ring-shaped structure that limits the conformational flexibility, and thus the entropic penalty, upon target binding ${ }^{3}$. The vast majority of macrocycle drugs are natural products or derivatives thereof ${ }^{4}$. For many targets, there are no available natural product-derived macrocycles, or the high complexity of the natural product hampers their synthetic modification and optimization. Thus, there is a need for synthetic macrocycles that are developed in a combinatorial fashion, which can greatly reduce the overall complexity. The necessary library diversity required to make these combinatorial macrocycles can be acquired by incorporating variable backbone structures (macrocyclic scaffold), by decorating the scaffolds with diverse functional groups, and by attaching peripheral substituents outside of the main ring. The variation of the macrocyclic scaffold is considered to be the most important determinant of structural diversity ${ }^{5}$. Therefore, a key step for achieving a high structural diversity in combinatorial macrocyclic libraries is to find a way to incorporate these variable scaffolds into the screening system. To this end, a range of elegant diversity-oriented synthesis strategies were published in recent years ${ }^{6}$. However, the development of strategies for diversifying the scaffolds 
in large combinatorial libraries comprising ideally millions of macrocycles remains an important challenge.

Display technologies such as phage and mRNA display have enabled the generation and screening of enormously large numbers of peptide macrocycles, typically reaching several billion compounds at a time ${ }^{7,8,9,10}$. Efficient chemical reactions allow for the transformation of genetically encoded linear peptides into cyclic structures, which can provide access to variably cyclized peptides while retaining the benefits of the genetically encoded library ${ }^{11,12}$. Typically, two or three amino acids are ligated to generate mono- or bicyclic peptide libraries. By combining orthogonal reactions, more complex macrocycle structures have also been generated. Recent technology innovations have enabled the incorporation of unnatural amino acids into mRNA display, expanding the diversity of chemical groups that can be used to build these types of libraries ${ }^{13,14,}$ 15. To this point, however, a major limitation of phage or mRNA display macrocyclic libraries is the low scaffold diversity. Due to the dependence on ribosomal translation, the backbones of the macrocycles are required to be polypeptidic in nature. In most of the reported libraries, the macrocycles contain a single polypeptide scaffold, and the diversity is based only on the variation of the amino acid side chains. By varying the number of amino acids in the random peptides ${ }^{14,16,}$ 17 or the chemical cyclization linkers ${ }^{18}$, libraries comprising several different scaffolds were generated, but none of the reported libraries were designed to contain more than a dozen different scaffolds.

Here we report an efficient and robust strategy for generating phage-encoded macrocyclic libraries that contain thousands of different scaffolds. We cyclize peptides through two chemical bridges that connect two pairs of cysteines (Fig. 1a). The two bridges subdivide the peptides into three segments containing $m, n$ and $o$ random amino acids, respectively (highlighted in red, orange and green in Fig. 1a). Altering the number of random amino acids in each segment in a combinatorial fashion allows for the generation of a much larger scaffold diversity than when peptides are divided by only two or three cysteines into fixed segments. Additional structural diversity stems from the connectivity between the cysteines, due to the fact that four cysteines can be connected by two chemical linkers in three different ways. The greater number of different bicyclic peptide scaffolds that can be generated with two chemical bridges as opposed to only one is exemplified for 9amino acid peptides in Fig. 1b. While cyclizing nonapeptides with one bridge (3 cysteines, 6 random amino acids) yields only 7 different bicyclic scaffolds, two bridges (4 cysteines, 5 random 
amino acids) yields 63 different bicyclic scaffolds. This already provides a nine-fold improvement in diversity that will increase with an increasing peptide size. For peptide macrocycles between 8 and 14 amino acids in length (including the four cysteines), a total of 798 different di-bridged bicyclic peptide formats can be obtained versus the 63 that are possible with a mono-bridge connecting three cysteines. The scaffold diversity can be further increased by cyclizing the same peptide library in parallel with many different chemical bridges that can further vary the ring size as well as include functional groups that can participate in binding. Dozens of reagents with two thiol-reactive groups are commercially available ${ }^{19,20,21}$, in direct contrast to the only two commercially available reagents with three symmetrical thiol-reactive groups ${ }^{18}$. The large scaffold diversity obtained by cyclizing peptides with two chemical bridges is illustrated in the animated supplementary slide show (provided as a PowerPoint presentation and animated gif). This calculation based on the cyclization of 8- to 14-mer peptides with 10 different bridges yields > 7000 different macrocyclic scaffolds. It is likely that some of these formats were already accidentally generated in previous work when cysteine alkylation was utilized for generating monocyclic peptide libraries of the form $\mathrm{CX}_{\mathrm{n}} \mathrm{C}$, and two additional cysteines appeared in the randomized region ${ }^{14,22,23,24,25}$. However, clones with four cysteines had such a low abundance in these libraries that no double-bridged peptides were isolated.

An important goal of our laboratory is the development of small, highly stable peptide macrocycles that can be applied topically or orally. Developing such small and compact ligands can be challenging because they have fewer amino acids that can interact with targets. We speculated that this handicap may be overcome by a molecular shape that is perfectly complementary to a target binding site, and that such molecules could potentially be isolated from macrocyclic libraries with high scaffold diversities. We thus applied the "double-bridge" cyclization strategy to smallsized peptides and used these to isolate inhibitors of plasma kallikrein. This protein is an important target of the swelling disorder hereditary angioedema to which injectable, protein-based inhibitors are already in clinical use ${ }^{26,27}$ or development ${ }^{28}$, but no small molecule drug is currently available.

\section{RESULTS}

A number of reagents containing thiol-reactive groups were reported to efficiently cross-link or cyclize peptides and proteins via cysteines in aqueous buffer and under mild conditions, including benzylbromides ${ }^{29,}{ }^{30}$, allylhalides ${ }^{31}$, haloacetamides ${ }^{32}$, haloacetones ${ }^{33}$, bromopyridazinediones $^{34}$ and bromomaleimides ${ }^{35}$. Of those, we chose 12 structurally diverse compounds and tested their 
ability to quantitatively and selectively link two pairs of cysteines in a model peptide in conditions

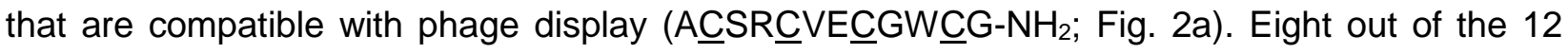
reagents produced the double-bridged peptide as the main product at a wide range of concentrations, suggesting that the reactions are robust and would work efficiently with peptides of variable sequences (Fig. 2b,c). The observed side products were mostly peptides with only one bridge and, at higher reagent concentrations, peptides that were modified with more than two linkers such that the cysteines were not bridged. Most of the thiol-reactive compounds did not inactivate filamentous phage or only interfered at concentrations far above those needed to fully cyclize the model peptide (Supplementary Fig. 1).

We applied the compounds 1, 3, 4, 7, 10, and 12 to two peptide phage display libraries each comprising more than 100 million random peptides of the formats $\mathrm{XCX}_{3} \mathrm{CX}_{3} \mathrm{CX}$-phage (library 1 ) and $\mathrm{XCX}_{4} \mathrm{CX}_{4} \mathrm{CX}$-phage (library 2). All of the peptides of these libraries contain cysteines in three fixed positions $(\mathrm{C})$, and some contain additional cysteines in the random positions $(X)$. There was a $20 \%$ and $23 \%$ chance, respectively, of a peptide containing four cysteines due to the probability of a cysteine occurring in the random, NNK-encoded positions. Cyclization of the peptides yielded 54 different backbone formats for each linker (Supplementary Fig. 2), producing 324 different macrocyclic scaffolds in total. The two libraries each cyclized with the six different linkers were individually panned against immobilized plasma kallikrein. High-throughput sequencing of phage isolated after two rounds of selection showed an enrichment for peptides containing four cysteines (Supplementary Table 1), that the fourth cysteine was localized to certain positions depending on the thiol-reactive reagent used (Fig. 3 for library 1; Supplementary Fig. 3 for library 2), and that peptides shared strong consensus sequences (Supplementary Fig. 4). These findings suggested that the library peptides were efficiently cyclized on phage, due to the strong prevalence of four cysteines, and that target-selective peptides were isolated because of the consensus. In phage selections with linkers 3 and $\mathbf{1 0}$, certain peptide formats were particularly enriched (Supplementary Fig. 4). For example, most peptides cyclized with linker 3 contained the fourth cysteine in amino acid position 3. In the selection with linker 10, many of the peptides isolated had the truncated format $\mathrm{XCX}_{2} \mathrm{CC}_{2} \mathrm{CX}$, which contained 10 instead of 11 amino acids. Such truncated peptides are generated during library cloning through erroneous DNA primers and occur only rarely in the finished library. The strong enrichment of some peptide formats, especially such rare formats, suggested that certain molecular scaffolds are particularly suited for target binding. This finding 
was the first hint that the high scaffold diversity obtained through the double-bridge strategy was key for the isolation of binders.

We synthesized several peptides and cyclized them by randomly bridging two pairs of cysteines through all three possible combinations, and each isomer was separately isolated and tested for binding. We picked the short peptides of 10 or 11 amino acids isolated from library 1 cyclized with linkers 3 and 10 due to our interest in small macrocycles ( 1200 Da). The $K_{\mathrm{i}} \mathrm{S}$ of the most active isomer for each peptide are indicated in Supplementary Fig. 4. Most of the peptides had activities in the nanomolar range, with some reaching sub-nanomolar $K_{\mathrm{i}} \mathrm{s}$. Because the cysteine connectivity of the inhibitors appeared to be important for the activity, the connectivity of two peptides, PK4 and PK6, was deciphered by synthesizing the three isomers using orthogonal cysteine protecting groups Mmt and Dpm (Supplementary Fig. 5 and 6). An efficient procedure including one on-resin cyclization was established that enabled the synthesis of double-bridged peptides in two days. For each peptide, there was one isomer that was much more active than the other isomers. It was determined that for PK4, isomer 3 (Cys1/Cys3, Cys2/Cys4) inhibited the protease with a $K_{\mathrm{i}}$ of 0.7 $\pm 0.1 \mathrm{nM}$ while the other two isomers showed at least a 200 -fold weaker inhibition (Fig. 4a). In PK6, isomer 1 (Cys1/Cys2, Cys3/Cys4) was by far the most active ( $K_{i}=3.2 \pm 0.5 \mathrm{nM}$ ) (Fig. 4a). Not surprisingly, the most active inhibitors of a consensus group had the same cysteine connectivity and thus the same macrocyclic scaffold.

The convergence of peptides to certain consensus groups based on the use of different linkers indicated an important structural and functional role for the chemical bridges. We assessed the role of the two linkers in the double-bridged peptides PK4 (isomer 3) and PK6 (isomer 1) in a structure-activity relationship (SAR) study in which we replaced one linker at a time to a set of diverse linkers (Fig. 4b, Supplementary Fig. 7, 8 and 9), some of which rendered the peptide macrocycles entirely inactive at the highest concentration tested $(1 \mu \mathrm{M})$. This linker swapping experiment showed that both of the two bridges are important. We then wondered if linker substitution could be a strategy for enhancing the macrocycles' inhibitory activities. To test this, we substituted linker 3 in the most active macrocycle PK2 (isomer $3 ; K_{i}=0.5 \pm 0.1 \mathrm{nM}$ ) with paradibromomethyl-benzene linkers 13-19 carrying diverse groups attached to the benzyl ring (Supplementary Fig. 10). While none of the macrocycles had an enhanced activity, we discovered that some of them again had a dramatically reduced activity, showing that even minor structural changes in the linker, such as the addition of small substituents, substantially impact the 
macrocycle activity. This suggested that linkers $13-19$, despite the similarity to 3 , should all be applied in parallel in future phage selections in order to generate even larger diversities.

The macrocycles PK2, PK4, and PK6 showed high target selectivity in a specificity profile performed with a panel of eight homologous trypsin-like serine proteases (Table 1). Six of the proteases were not inhibited at all. Even coagulation factor Xla (FXla), sharing the highest sequence identity with plasma kallikrein (69\% amino acid homology in the catalytic domain), was only weakly inhibited, and the macrocycles still demonstrated around 1000-fold selectivity for plasma kallikrein over FXla. We subsequently investigated the structural determinants of the target specificity for one of the macrocycles, PK2. Specifically, we tested if PK2 could be turned into a FXla inhibitor by mutating different amino acids (Fig. 4c; Supplementary Fig. 11), but none of the substitutions improved the inhibition of FXla. Detrimental mutations reduced the inhibition of both proteases to similar extents, indicating that the macrocycle binds both proteases through similar key contacts. Apparently, the backbone formed by a $\mathrm{XCCX}_{2} \mathrm{CX}_{3} \mathrm{CX}$ peptide double-bridged by linker $\mathbf{3}$ fits perfectly to the active site of plasma kallikrein and contributes to the target selectivity.

Short peptides constrained by two linkers promised a high proteolytic stability due to the inaccessibility of the peptide backbone to proteases. Indeed, some of the double-bridged peptides, like PK2 (isomer 3), showed an impressive stability in human plasma at $37^{\circ} \mathrm{C}$ (Fig. 5a). While the two exocyclic amino acids were cleaved by proteases, first the $\mathrm{N}$-terminal serine $\left(\mathrm{t}_{1 / 2}=29 \mathrm{~min}\right)$ followed by the $\mathrm{C}$-terminal tyrosine $\left(\mathrm{t}_{1 / 2}=6.9\right.$ hours), the double-bridged macrocycle core remained intact after two days. The high stability of PK2 most likely results from interlaced bridging that tightly connects the two macrocycles, reducing their conformational flexibility and/or rendering them less accessible to proteases. This was confirmed by testing a peptide, PK6 (isomer 1), lacking the interlaced configuration due to bridges between Cys1/Cys2 and Cys3/Cys4, which was rapidly degraded $\left(\mathrm{t}_{1 / 2} \sim 5\right.$ minutes; Fig. $5 \mathrm{~b}$ ). For PK2, the loss of the terminal amino acids reduced the activity of the peptide 4-fold (Ser1) and 108-fold (Tyr11), respectively (Fig. 5c). To mitigate this loss, we tested a small set of peptides in which the vulnerable exocyclic residues were replaced by D-amino acids (Fig. 5c). Appending D-Arg at the $\mathrm{N}$-terminus and D-Tyr at the C-terminus increased the inhibitory activity 1.9- and 9.6-fold, respectively. The resulting macrocycle PK10 had a $K_{\mathrm{i}}$ of $3.6 \pm 0.5 \mathrm{nM}$, compared to $0.5 \pm 0.1 \mathrm{nM}$ for the PK2 precursor, though remained fully intact upon incubation in plasma ( $\mathrm{t}_{1 / 2}>3$ days; Fig. $5 c$ and $\left.5 \mathrm{~d}\right)$. 
Plasma kallikrein plays a role in various diseases including hereditary angioedema (HEA), diabetic macular edema, and thrombosis, and contributes to contact activation in extracorporeal circulation during procedures such as coronary artery bypass grafting. Two protein-based inhibitors, C1 inhibitor and ecallantide, are approved for the treatment of acute HEA attacks ${ }^{26,27}$. Several drug development programs are ongoing to generate antibody (e.g. lanadelumab) or small molecule inhibitors of plasma kallikrein ${ }^{28,36}$. We tested if the double-bridged peptides could block the activation of the intrinsic coagulation pathway in human plasma, which is dependent on the reciprocal activation of plasma kallikrein and factor XII (FXII). Human plasma was incubated with inhibitor, the activation of FXII was triggered by Pathromtin®, and the time to coagulation was measured to determine the activated partial thromboplastin time (aPTT). The peptides PK2, PK4, PK6, and PK10 all efficiently inhibited activation of the intrinsic coagulation pathway in human plasma ex vivo (Fig. 5e); PK10 doubled the aPTT (EC $2 x$ ) at a concentration of $3 \mu \mathrm{M}$.

In order to test if double-bridged peptides could be developed to other protein targets, we performed selections against the cytokine IL-17, for which antibody drugs but not small molecules are in clinical use ${ }^{37}$. We designed and cloned a new phage library displaying peptides of the format $\mathrm{XCX}_{\mathrm{m}} \mathrm{CX}_{\mathrm{n}} \mathrm{CX}{ }_{\circ} \mathrm{CX}$ that all contain four cysteines in fixed positions (library $3, \mathrm{~m}+\mathrm{n}+\mathrm{0}=3-8,155$ formats, library size: $2 \times 10^{10}$, Supplementary Fig. 12). Cyclization of library 3 with the same reagents that were applied to libraries 1 and $2(\mathbf{1}, \mathbf{3}, \mathbf{4}, \mathbf{7}, \mathbf{1 0}, \mathbf{1 2})$ and a new reagent, divinylsulfone (20) yielded a total of 3,255 different macrocyclic backbones, and thus an even larger scaffold diversity than that of the libraries described above. After three rounds of affinity selection against IL-17, peptides modified with the two reagents 10 and 20 were strongly enriched over the negative control (no target protein immobilized) and were analyzed further. High-throughput DNA sequencing showed that peptides containing four cysteines were highly abundant (>90\%, Supplementary Table 2) and identified multiple consensus groups (Fig. 6a). Peptides modified with reagent 10 and containing the consensus motif $\mathrm{W}^{\mathrm{F}} / \mathrm{Y} / \mathrm{E} F$ or DYWYGF showed nanomolar binding affinities when the peptides were synthesized as mixtures of the three regioisomers. We synthesized the regioisomers of two of the peptides individually and determined the $K_{d}$ values by fluorescence polarization (Fig. 6a and Supplementary Fig. 13). Like the plasma kallikrein inhibitors, we found that one of the three isomers was far more active than the other two. This was particularly remarkable as two of the isomers, 2 and 3, have a similar backbone and present the consensus motif in a similar manner (Fig. 6b). The best ligand, IL17-2 isomer 3, bridged at Cys1/Cys3 and Cys2/Cys4, bound IL-17 with a $K_{d}$ of $36 \pm 3$ nM (Fig. 6c). 


\section{DISCUSSION}

We show that macrocyclic peptide libraries with a large structural diversity can be generated by cyclizing peptides with two chemical bridges that each connect a pair of cysteines. This approach yielded libraries comprising far more different macrocyclic scaffolds than any previously developed libraries, which tend to be based on one or, at the most, a handful of different scaffolds. Highthroughput sequencing of isolated peptides revealed a strong preference for certain peptide formats, clearly showing the importance of the large scaffold diversity. Even though the new strategy generates three macrocyclic isomers that are all encoded by the same phage DNA, we show that multiple products do not impair the phage panning procedure, that the three isomers can be efficiently synthesized with an orthogonal protection strategy, and that the active isomer can easily be identified. Once the active isomer of a consensus group is found, more peptides of the same group can be synthesized directly with the correct cysteine connectivity in order to efficiently screen for the most active sequence.

For both targets used in this study, plasma kallikrein and IL-17, high-affinity double-bridged peptides could be developed. As a direct comparison, similarly sized bicyclic peptides (11 amino acids) that were cyclized by only one chemical linker (connecting three cysteines) were previously developed to plasma kallikrein by screening the same type of library $\left(\mathrm{XCX}_{3} \mathrm{CX}_{3} \mathrm{CX}\right)^{38}$. The best bicyclic peptide plasma kallikrein inhibitor developed through these pans had a $K_{\mathrm{i}}$ of $5.2 \mathrm{nM}$ and thus a 10-fold weaker binding affinity than the di-bridged peptides. It is likely that the affinity improvement can be attributed to the larger scaffold diversity that was generated and sampled with the new approach. A plasma kallikrein inhibitor with a comparable affinity $\left(K_{\mathrm{i}}=0.3 \mathrm{nM}\right)$ was previously obtained only by screening a library of much longer bicyclic peptides that form a larger binding interface with the target ( 15 amino acids of the form $\mathrm{XCX}_{5} \mathrm{CX}_{5} \mathrm{CX}$ cyclized by one linker) ${ }^{38}$. The development of smaller macrocycles with a molecular weight approaching $1 \mathrm{kDa}$ is of interest for the development of drugs amenable to topical or oral administration. Several orally available peptide macrocycles, including cyclosporin and desmopressin (both $1.2 \mathrm{kDa}$ ) have molecular weights in this range, suggesting that phage-selected, double-bridged peptides might be applied as leads for the development of topical or oral drugs. 
The SAR study revealed that both of the two chemical bridges in the bicyclic peptides are essential for binding, wherein one bridge was slightly more important in all of the examples studied. Substitution to structurally similar bridges reduced the binding affinity, suggesting that cyclizing peptide phage libraries in parallel with similar reagents such as compounds 13-19 will allow for the generation of even larger macrocycle diversities. More reagents containing two thiol-reactive groups are commercially available, and a nearly endless number of such compounds can be designed and synthesized. A SAR study altering the amino acid sequence of double-bridged peptide PK2 showed that its high target selectivity was based, at least to some extent, on the specific peptide backbone architecture. None of the numerous amino acid mutations tested increased the affinity for the homologous protease FXla. This is in stark contrast to the previously developed single-bridged bicyclic peptide inhibitors of plasma kallikrein that also inhibited FXla when specific amino acid positions were mutated ${ }^{38}$. This observation is an additional indication that the larger scaffold diversity allowed for the identification of ligands that are perfectly complementary in shape and polarity to the target binding site.

An interesting feature of the ligands with interlaced bridges is the high proteolytic stability. The core structure of PK2 resisted protease degradation when it was incubated for several days in human plasma at $37^{\circ} \mathrm{C}$. This high stability is likely due to the close connection of the two macrocyclic rings, resulting from interlacing bridges Cys $1 /$ Cys3 and Cys2/Cys4. This hypothesis is further supported by the low proteolytic stability of the double-bridged PK6 that contains two independent monocycles connected via a flexible linker. The enormous stability of the interlaced peptide macrocycle format might be exploited for the development of oral drugs that must survive the proteolytic pressure in the gastrointestinal tract. This could include either drugs that are absorbed into the bloodstream or that act on targets in the gastrointestinal tract. The feasibility of peptide-based drugs acting in the lumen of the gastrointestinal tract is demonstrated with the recently approved blockbuster drug linaclotide. This 14-amino acid peptide derived from nature and stabilized by three disulfide bridges is orally applied. The low stability for exocyclic amino acids, such as the Ser1 and Tyr11 in PK2, should therefore not be a limitation as they can be substituted to non-natural building blocks that resist proteolytic cleavage, as demonstrated in this work. Alternatively, exocyclic amino acids may be completely omitted and the loss in affinity compensated by substituting amino acids in the core to unnatural ones that can more efficiently bind the target. The latter strategy would allow a further reduction of the molecular weight of the ligands, and would reduce the size of PK2 to below $1 \mathrm{kDa}$. 
In summary, we have developed an efficient strategy for the generation and screening of macrocyclic peptide libraries comprising an unprecedented scaffold diversity. We show that ligands with a better affinity and target selectivity can be isolated from such libraries despite a rather small molecular mass of the compounds, and that a scaffold format with interlaced macrocyclic rings has a particularly high stability. The combined properties of the generated ligands including high affinity and selectivity, small size, and high proteolytic stability make them interesting as drug development leads. 


\section{DATA AVAILABILITY STATEMENT}

The principal data supporting the findings of this work are available within the figures and the Supplementary Information. All other data are available from the corresponding author upon request.

\section{ACKNOWLEDGEMENTS}

This work was supported by the NCCR Chemical Biology of the Swiss National Science Foundation.

\section{AUTHOR CONTRIBUTIONS}

S.K., C.V., X.K. and C.H. conceived the strategy, designed experiments, analyzed data and wrote the manuscript. S.K. established the chemical reactions. C.V. and X.K. performed the phage selections. S.K., C.V. and X.K. synthesized, purified and characterized peptides. A.Z. synthesized a linker reagent. K.D. contributed to the writing of the manuscript. S.K., C.V., X.K. contributed equally to this work.

\section{COMPETING FINANCIAL INTERESTS}

C.H. is a scientific founder of Bicycle Therapeutics. All other authors do not declare a COI. 


\section{REFERENCES}

1. Driggers, E. M., Hale, S. P., Lee, J. \& Terrett, N. K. The exploration of macrocycles for drug discovery - an underexploited structural class. Nature Rev. Drug Discov. 7, 608-624 (2008).

2. Macrocycles in Drug Discovery, vol. 40. Royal Society of Chemistry: Cambridge (2014).

3. Villar, E. A. et al. How proteins bind macrocycles. Nature Chem. Biol. 10, 723-731 (2014).

4. Giordanetto, F. \& Kihlberg, J. Macrocyclic Drugs and Clinical Candidates: What Can Medicinal Chemists Learn from Their Properties? J. Med. Chem. 57, 278-295 (2014).

5. Dow, M., Fisher, M., James, T., Marchetti, F. \& Nelson, A. Towards the systematic exploration of chemical space. Org. Biomol. Chem. 10, 17-28 (2012).

6. Collins, S., Bartlett, S., Nie, F. L., Sore, H. F. \& Spring, D. R. Diversity-Oriented Synthesis of Macrocycle Libraries for Drug Discovery and Chemical Biology. Synthesis-Stuttgart 48, 1457-1473 (2016).

7. Chen, S. \& Heinis, C. Phage Selection of Mono- and Bicyclic Peptide Ligands. In: Jones, L. \& McKnight, A. J. (eds). Biotherapeutics: Recent Developments using Chemical and Molecular Biology. Royal Socienty of Chemistry, 241-262 (2013).

8. Josephson, K., Ricardo, A. \& Szostak, J. W. mRNA display: from basic principles to macrocycle drug discovery. Drug Discov. Today 19, 388-399 (2014).

9. Ladner, R. C., Sato, A. K., Gorzelany, J. \& de Souza, M. Phage display-derived peptides as a therapeutic alternatives to antibodies. Drug Discov. Today 9, 525529 (2004).

10. Obexer, R, L. J. W \& Suga, H. Exploring sequence space: harnessing chemical and biological diversity towards new peptide leads. Curr. Opin. Chem. Biol. 38, 5261 (2017). 
11. Heinis, C. \& Winter, G. Encoded libraries of chemically modified peptides. Curr. Opin. Chem. Biol. 26, 89-98 (2015).

12. Ng, S., Jafari, M. R. \& Derda, R. Bacteriophages and Viruses as a Support for Organic Synthesis and Combinatorial Chemistry. ACS Chem. Biol. 7, 123-138 (2012).

13. Bashiruddin, N. K., Nagano, M. \& Suga, H. Synthesis of fused tricyclic peptides using a reprogrammed translation system and chemical modification. Bioorg. Chem. 61, 45-50 (2015).

14. Hacker, D. E., Hoinka, J., Iqbal, E. S., Przytycka, T. M. \& Hartman, M. C. T. Highly Constrained Bicyclic Scaffolds for the Discovery of Protease-Stable Peptides via mRNA Display. ACS Chem. Biol. 12, 795-804 (2017).

15. Sako, Y., Morimoto., J., Murakami, H. \& Suga, H. Ribosomal synthesis of bicyclic peptides via two orthogonal inter-side-chain reactions. J. Am. Chem. Soc. 130, 7232-7234 (2008).

16. Hayashi, Y., Morimoto, J. \& Suga, H. In Vitro Selection of Anti-Akt2 ThioetherMacrocyclic Peptides Leading to Isoform-Selective Inhibitors. ACS Chem. Biol. 7, 607-613 (2012).

17. Rebollo, I. R., Angelini, A. \& Heinis, C. Phage display libraries of differently sized bicyclic peptides. Medchemcomm 4, 145-150 (2013).

18. Chen, S., Bertoldo, D., Angelini, A., Pojer, F. \& Heinis C. Peptide Ligands Stabilized by Small Molecules. Angew. Chem. Int. Edit. 53, 1602-1606 (2014).

19. Chua, K. et al. Small cyclic agonists of iron regulatory hormone hepcidin. Bioorg. \& Med. Chem. Lett. 25, 4961-4969 (2015).

20. Jo H. et al. Development of alpha-Helical Calpain Probes by Mimicking a Natural Protein-Protein Interaction. J. Am. Chem. Soc. 134, 17704-17713 (2012).

21. Kowalczyk, R. et al., Synthesis and evaluation of disulfide bond mimetics of amylin(1-8) as agents to treat osteoporosis. Bioorg. \& Med. Chem. Lett. 20, 2661-2668 (2012). 
22. Bellotto, S., Chen, S., Rentero Rebollo, I., Wegner, H. A. \& Heinis, C. Phage selection of photoswitchable peptide ligands. J. Am. Chem. Soc. 136, 5880-5883 (2014).

23. Jafari, M. R. et al. Discovery of light-responsive ligands through screening of a lightresponsive genetically encoded library. ACS Chem. Biol. 9, 443-450 (2014).

24. Ng, S. \& Derda, R. Phage-displayed macrocyclic glycopeptide libraries. Org. Biomol. Chem. 14, 5539-5545 (2016).

25. Schlippe, Y. V., Hartman, M. C., Josephson, K. \& Szostak, J. W. In vitro selection of highly modified cyclic peptides that act as tight binding inhibitors. J. Am. Chem. Soc. 134, 10469-10477 (2012).

26. Cicardi, M. et al. Ecallantide for the Treatment of Acute Attacks in Hereditary Angioedema. New Engl. J. Med. 363, 523-531 (2010).

27. Plosker, G. L. Recombinant Human $\mathrm{C} 1$ Inhibitor (Conestat Alfa) In the Treatment of Angioedema Attacks in Hereditary Angioedema. Biodrugs 26, 315-323 (2012).

28. Banerji, A. et al. Inhibiting Plasma Kallikrein for Hereditary Angioedema Prophylaxis. New Engl. J. Med. 376, 717-728 (2017).

29. Smeenk, L. E. J., Dailly, N., Hiemstra, H., Maarseveen, J. H. v. \& Timmerman, P. Synthesis of Water-Soluble Scaffolds for Peptide Cyclization, Labeling, and Ligation. Org. Lett. 14, 1194-1197 (2012).

30. Timmerman, P., Beld, J., Puijk, W. C. \& Meloen, R. H. Rapid and quantitative cyclization of multiple peptide loops onto synthetic scaffolds for structural mimicry of protein surfaces. ChemBioChem 6, 821-824 (2005).

31. Wang, Y. \& Chou, D. H. C. A Thiol-Ene Coupling Approach to Native Peptide Stapling and Macrocyclization. Angew. Chemie Int. Ed. 54, 10931-10934 (2015).

32. Woolley, G. A. Photocontrolling peptide alpha helices. Accounts Chem. Res. 38, 486-493 (2005). 
33. Assem, N., Ferreira, D. J., Wolan, D. W. \& Dawson, P. E. Acetone-Linked Peptides: A Convergent Approach for Peptide Macrocyclization and Labeling. Angew. Chem. Int. Edit. 54, 8665-8668 (2015).

34. Lee, M. T. W., Maruani, A. \& Chudasama, V. The use of 3,6-pyridazinediones in organic synthesis and chemical biology. J. Chem. Res. 1, 1-9 (2016).

35. Smith, M. E. B. et al. Protein Modification, Bioconjugation, and Disulfide Bridging Using Bromomaleimides. J. Am. Chem. Soc. 132, 1960-1965 (2010).

36. Li, Z. et al. Structure-Guided Design of Novel, Potent, and Selective Macrocyclic Plasma Kallikrein Inhibitors. ACS Med. Chem. Lett. 8, 185-190 (2017).

37. Tse, M. T. IL-17 antibodies gain momentum. Nature Rev. Drug Discov. 12, 815816 (2013).

38. Baeriswyl, V. et al. Bicyclic Peptides with Optimized Ring Size Inhibit Human Plasma Kallikrein and its Orthologues While Sparing Paralogous Proteases. ChemMedChem 7, 1173-1176 (2012).

39. Coleman, R. S. \& Pires, R. M. Covalent cross-linking of duplex DNA using 4-thio2'-deoxyuridine as a readily modifiable platform for introduction of reactive functionality into oligonucleotides. Nucleic Acids Res. 25, 4771-4777 (1997).

40. Rebollo, I. R. \& Heinis, C. Phage selection of bicyclic peptides. Methods 60, 46-54 (2013).

41. Rentero Rebollo, I., Sabisz, M., Baeriswyl, V. \& Heinis, C. Identification of targetbinding peptide motifs by high-throughput sequencing of phage-selected peptides. Nucleic Acids Res. 42, e169 (2014). 


\section{FIGURE CAPTIONS}

Figure 1 Cyclization of peptides with two chemical bridges. a, Cyclization of peptides with two chemical bridges (connecting four cysteines) yields a much larger number of bicyclic peptide scaffolds than cyclization with one bridge (connecting three cysteines). This is mainly because more permutations are possible for the positions of four cysteines in a peptide. The table on the right shows the number of different macrocyclic scaffolds that can be formed for peptides of the indicated length, when the peptides are cyclized via three cysteines with one bridge, or via four cysteines with two bridges. $\mathbf{b}$, Illustration of the large macrocycle diversity with a double-bridged nonapeptide as an example.

Figure 2 Cyclization reagents and reaction efficiency. a, Chemical linkers each containing two

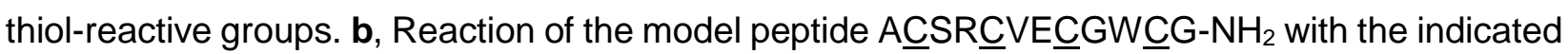
concentrations of chemical linker 3. Products were analyzed by analytical HPLC and mass spectrometry. At all reagent concentrations, the major products were the three desired doublebridged peptides. c, Products formed upon incubation of the model peptide with twelve different chemical reagents at the indicated concentrations. Fields shaded with dark gray indicate that the major product was the double-bridged peptide (sum of three isomers $>50 \%$ of total product). Minor products are indicated with small letters: a. bicyclic peptide, b. non-bridged modification, c. single bridge, d. not identified.

Figure 3 Phage selection of double-bridged peptides. Peptides of the phage library 1 $\left(\mathrm{XCX}_{3} \mathrm{CX}_{3} \mathrm{CX}\right.$-phage) were cyclized in individual reactions with the indicated linkers, subjected to two rounds of selection against plasma kallikrein, and the formats of isolated peptides analyzed. Modification with different linkers led to enrichment of different peptide formats. The abundance of the various peptide formats is indicated in \% of those peptides containing four cysteines. Abundance of peptide formats enriched from library 2 is shown in Supplementary Fig. 3.

Figure 4 Role of chemical bridges. a, Structures of the three isomers of PK4 and PK6. The residual activity of plasma kallikrein in presence of different concentrations of the isomers was measured using a fluorogenic substrate. Mean values of the residual activity and standard deviations of three measurements are shown. One out of the three isomers efficiently inhibits plasma kallikrein. HPLC traces of the active isomers are shown in Supplementary Fig. 6. b. Replacement of the chemical 
bridges in PK4 and PK6 reduced the inhibitory activity to various extents. Mean values and standard deviations of three measurements are indicated. Even small structural changes in the bridges affected the binding affinity, indicating the important role of the bridges. c, SAR study of PK2 (isomer 3). Inhibition of plasma kallikrein and FXla by PK2 variants with the indicated amino acid substitutions. The $K_{\mathrm{i}} \mathrm{s}$ are indicated.

Figure 5 Stability of double-bridged peptides. a, Proteolytic degradation of PK2 (isomer 3) and PK6 (isomer 1) in human plasma analyzed by LC-MS. Total ion count (TIC) in SIM mode of identified species is shown. $\mathbf{b}$, Inhibitory activities of $\mathrm{N}$ - or C-terminally modified PK2 (isomer 3). Average values and standard deviations of $K_{\mathrm{i}}$ s were calculated from at least three measurements. c, LC-MS analysis of PK10 after incubation in human blood plasma. d, Fraction of functional PK10 after incubation in human blood plasma as determined in a plasma kallikrein inhibition assay. Mean values and standard deviations of three measurements are indicated. e, Inhibition of the intrinsic coagulation pathway. Coagulation time (aPTT) was measured in human blood ex vivo at different concentrations of the indicated plasma kallikrein inhibitors. Mean values and standard deviations of three measurements are indicated.

Figure 6 Double-bridged peptides selected against IL-17. a, Peptides isolated from library 3 after three rounds of panning using linker 10 or 20. Peptides with similar sequences are aligned in groups and amino acid similarities are highlighted in color. Regioisomers of two peptides were synthesized with fluorescein linked to their N-terminus to measure binding to IL-17 by fluorescence polarization. Standard deviations are indicated for the $K_{d}$ values. b. Schematic drawing of the three isomers of IL17-2. c, Binding of the three regioisomers of IL17-2 to IL-17 was measured by fluorescence polarization. Mean values and standard deviations of three measurements are indicated. 
TABLE

\begin{tabular}{|c|c|c|c|c|}
\hline & \multicolumn{4}{|c|}{$K_{\mathrm{i}}(\mathrm{nM})$} \\
\hline & PK2 & PK4 & PK6 & PK10 \\
\hline plasma kallikrein & $0.5 \pm 0.1$ & $0.7 \pm 0.1$ & $3.2 \pm 0.5$ & $3.6 \pm 0.5$ \\
\hline factor Xla & $580 \pm 180$ & $1300 \pm 500$ & $2700 \pm 200$ & $2500 \pm 100$ \\
\hline factor XIla & $>30000$ & $>30000$ & $>30000$ & $>30000$ \\
\hline thrombin & $>30000$ & $>30000$ & $>30000$ & $>30000$ \\
\hline uPA & $>30000$ & $>30000$ & $>30000$ & $>30000$ \\
\hline tPA & $>30000$ & $>30000$ & $>30000$ & $>30000$ \\
\hline plasmin & $>30000$ & $>30000$ & $>30000$ & $>30000$ \\
\hline factor Xa & $>30000$ & $>30000$ & $>30000$ & $>30000$ \\
\hline factor VIla & $>30000$ & $>30000$ & $>30000$ & $>30000$ \\
\hline
\end{tabular}

Table 1 Target specificity. Inhibition of plasma kallikrein and a panel of structurally homologous or physiologically important paralogous proteases by isolated inhibitors. Average values and standard deviations of at least three measurements are indicated. 


\section{Table of Contents Summary}

Linking in peptides two pairs of cysteines with chemical bridges provides rapid access to thousands of different macrocyclic scaffolds in libraries that are easy to synthesize, screen, and decode. Application of this strategy to phage-encoded libraries yielded binders with remarkable affinities despite the small molecular mass. 


\section{FIGURES}

Figure 1

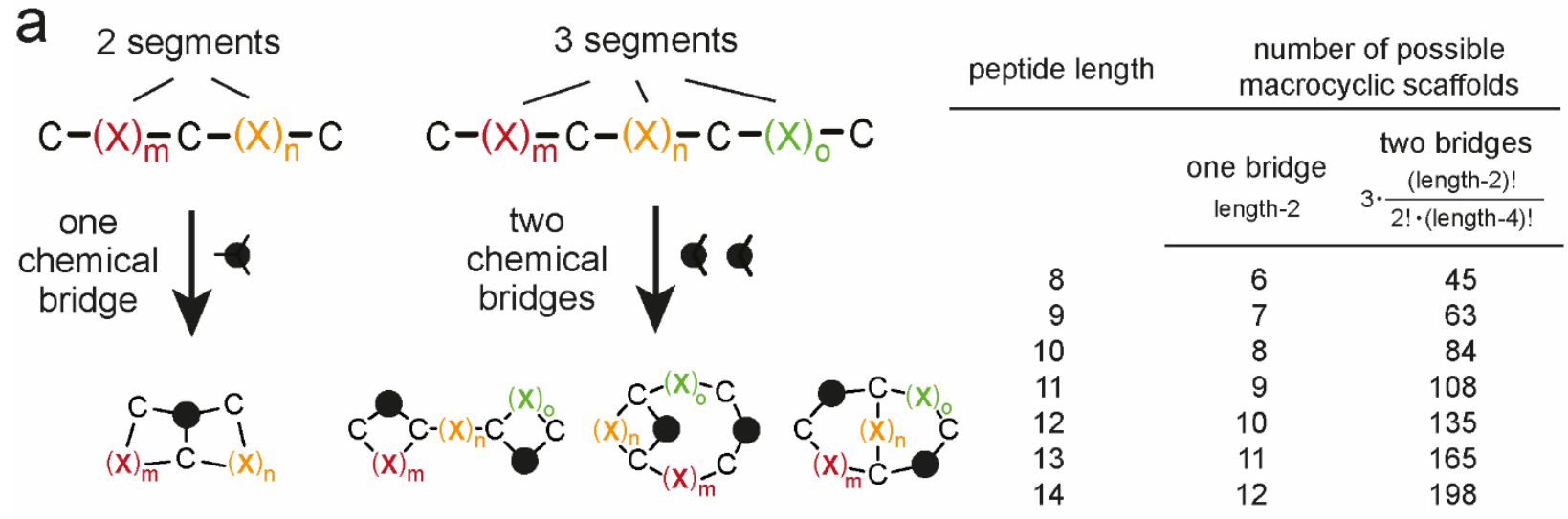

b example: 9-amino acid peptides

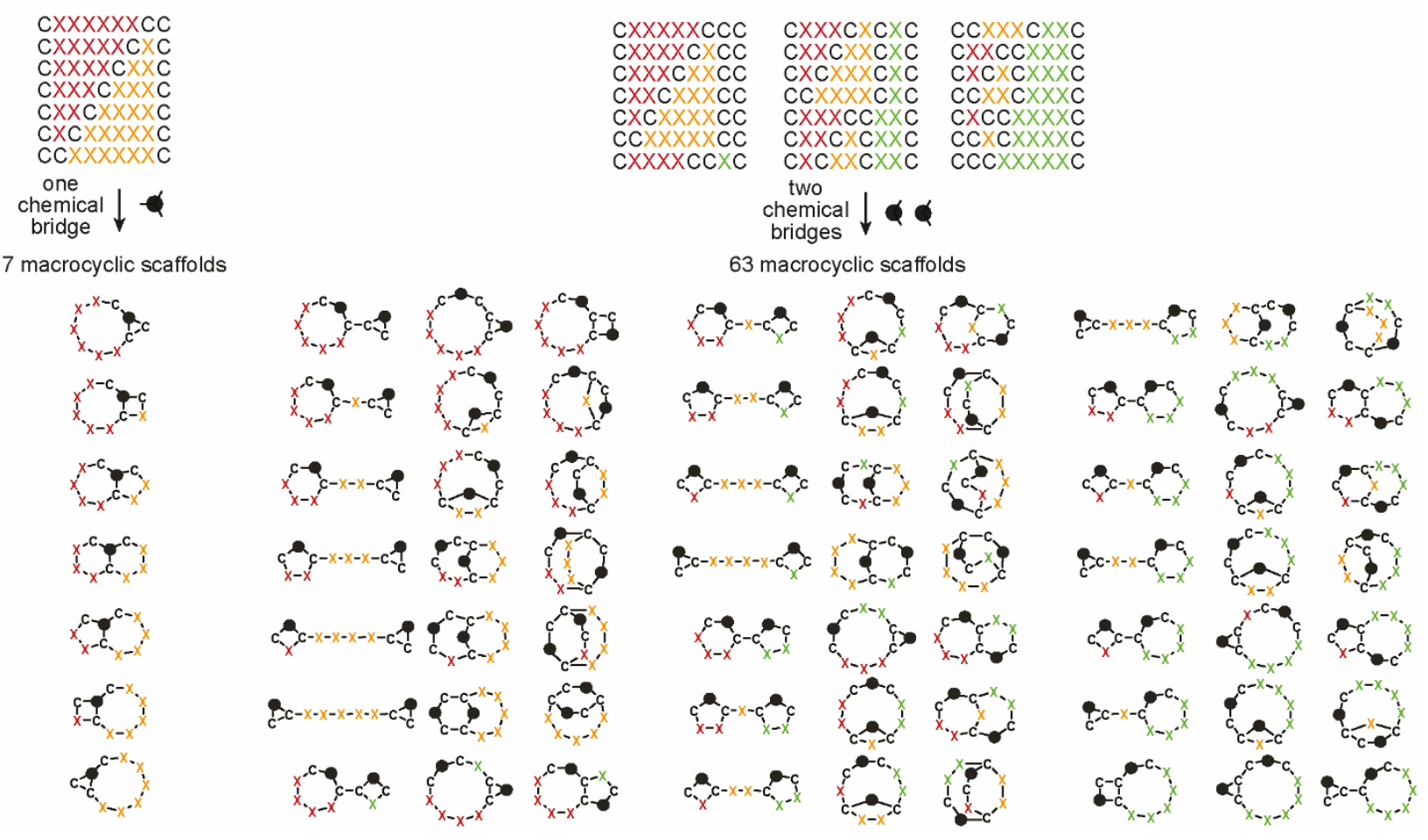


Figure 2

a<smiles>C=C(CBr)CBr</smiles><smiles>NC(=O)C(Br)(Br)C(=O)N[13C](Br)(Br)C(=O)Nc1cccc(NC(=O)CBr)c1</smiles>

b

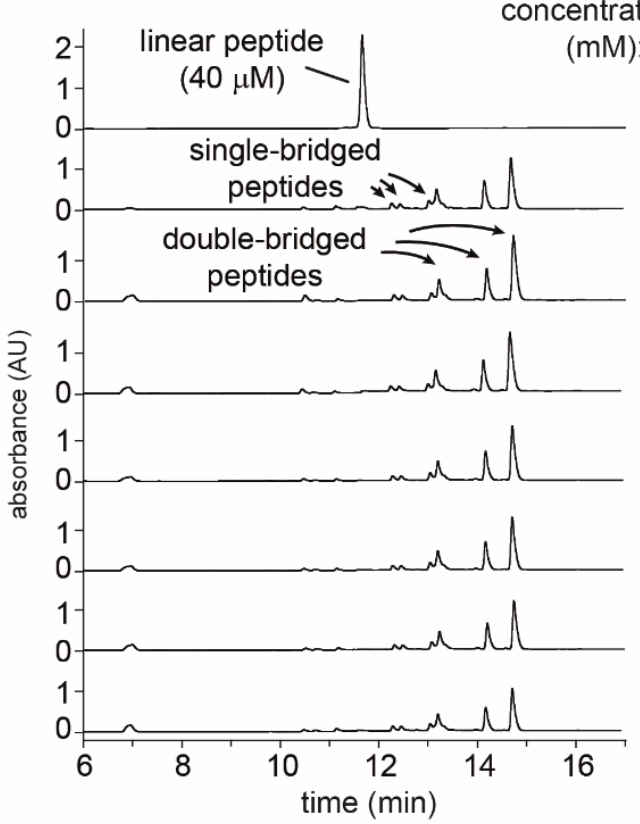

C concentration $(\mathrm{mM})$

$\begin{array}{llllllll}\text { bridge } & 0.1 & 0.2 & 0.4 & 0.8 & 1.6 & 3.2 & 6.4\end{array}$ (mM): bridge

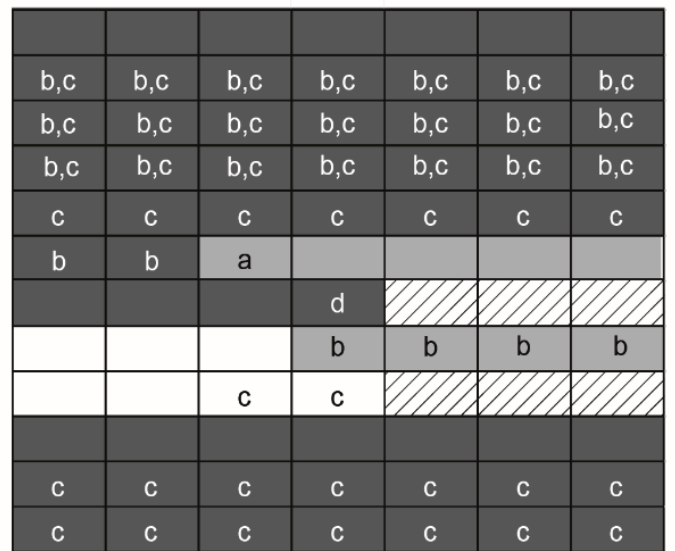

3.2

major product:

$6.4 \square$ unreacted peptide $\square$ double-bridged peptide non-bridged modific. $\square$ not identified product 
Figure 3

\begin{tabular}{|c|c|c|c|c|c|c|c|}
\hline \multirow[t]{2}{*}{ peptide format: } & \multicolumn{7}{|c|}{$\%$ of peptides (among those having 4 cysteines) } \\
\hline & linker: & 1 & 3 & 4 & 7 & 10 & 12 \\
\hline$c(\times \times \times C \times \times \times c)$ & $x$ & $18 \%$ & | $5 \%$ & & | $7 \%$ & $\mid 1 \%$ & 3 \\
\hline$\times C \subset \times \times C \times \times \times C$ & & $10 \%$ & $86 \%$ & $32 \%$ & $11 \%$ & | $5 \%$ & $13 \%$ \\
\hline$\times C \times c \times c \times \times \times c)$ & & $1 \%$ & $0 \%$ & $7 \%$ & $2 \%$ & $0 \%$ & $3 \%$ \\
\hline$\times(\times \times C(\times \times \times C)$ & & $43 \%$ & $\mid 3 \%$ & $18 \%$ & & $18 \%$ & $11 \%$ \\
\hline$\times(\times \times \times C(\times \times C)$ & & $4 \%$ & $\mid 1 \%$ & $9 \%$ & $15 \%$ & $14 \%$ & $19 \%$ \\
\hline$\times C \times \times \times C \times C \times C$ & & $5 \%$ & $0 \%$ & $0 \%$ & $0 \%$ & $0 \%$ & $4 \%$ \\
\hline$\times C \times \times \times C \times \times C C$ & & $6 \%$ & $\mid 3 \%$ & | $8 \%$ & | $5 \%$ & $14 \%$ & $13 \%$ \\
\hline$\times C \times \times \times C \times \times \times c$ & & $13 \%$ & $\mid 2 \%$ & $14 \%$ & $12 \%$ & $2 \%$ & $4 \%$ \\
\hline$X C \times X C C \times \times C X$ & & & $0 \%$ & & $0 \%$ & 46 & \\
\hline
\end{tabular}


Figure 4

a

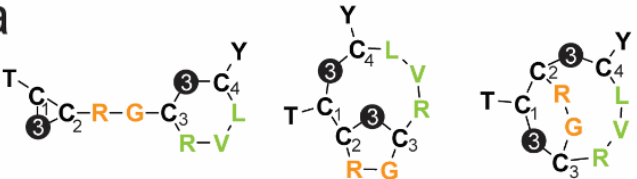<smiles>Cc1csc(-c2nnc(-c3cccs3)o2)c1</smiles>

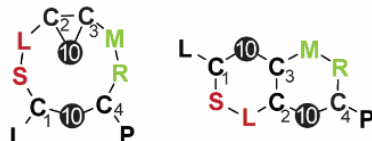

PK4 isomer 1 PK4 isomer 2 PK4 isomer 3

PK6 isomer 1 PK6 isomer 2 PK6 isomer 3
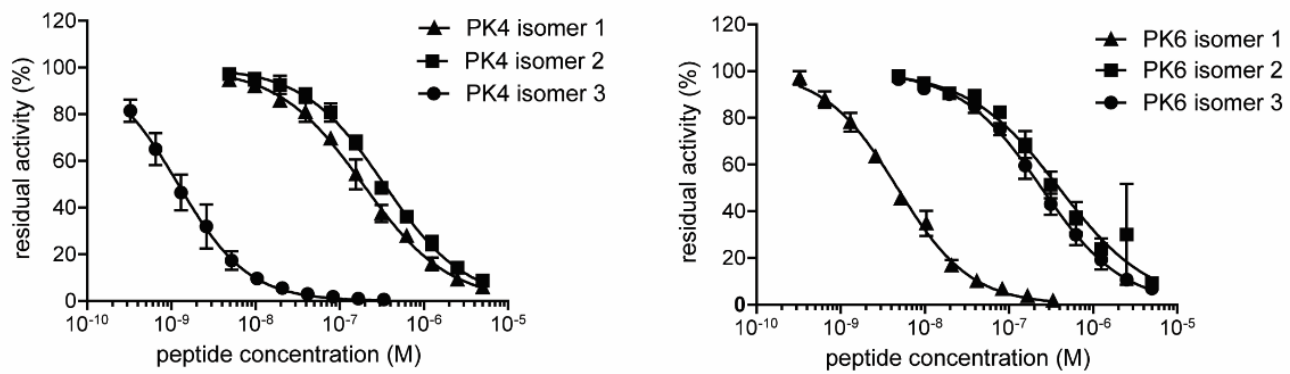

b
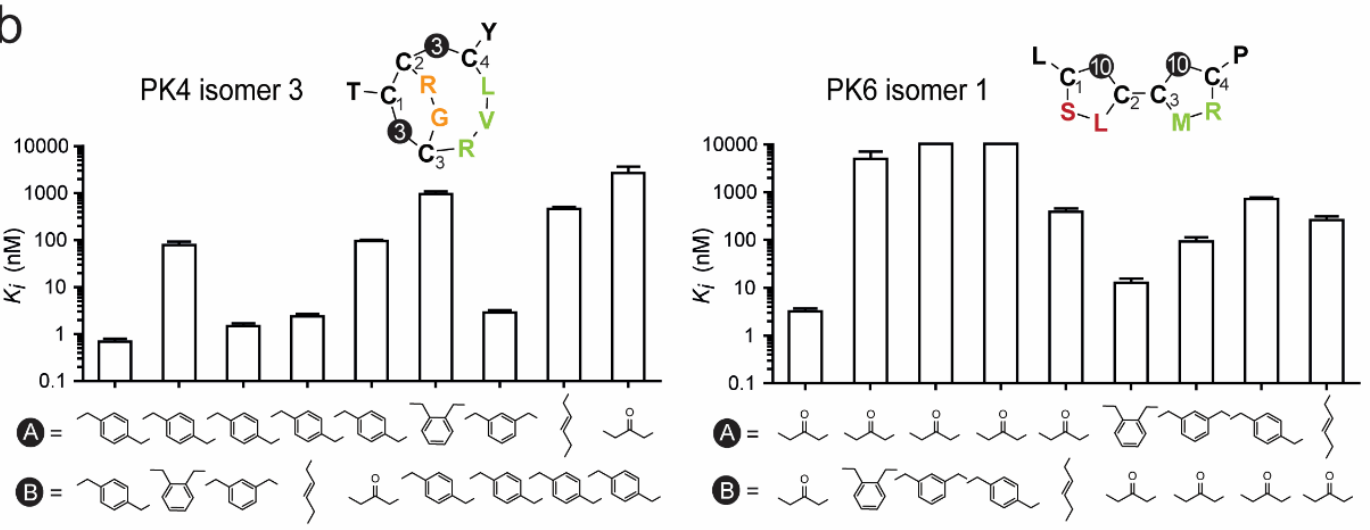

C

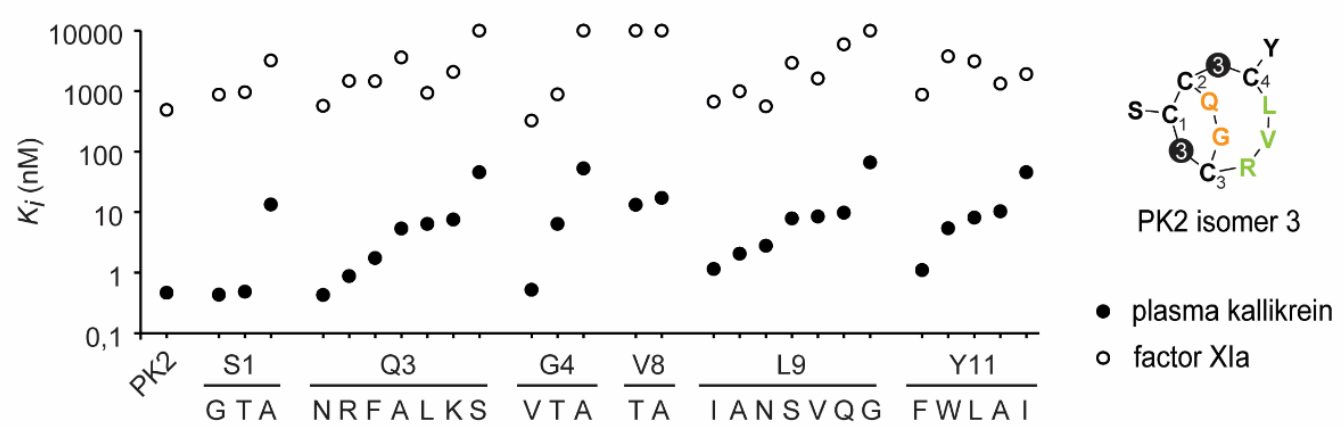


Figure 5

a
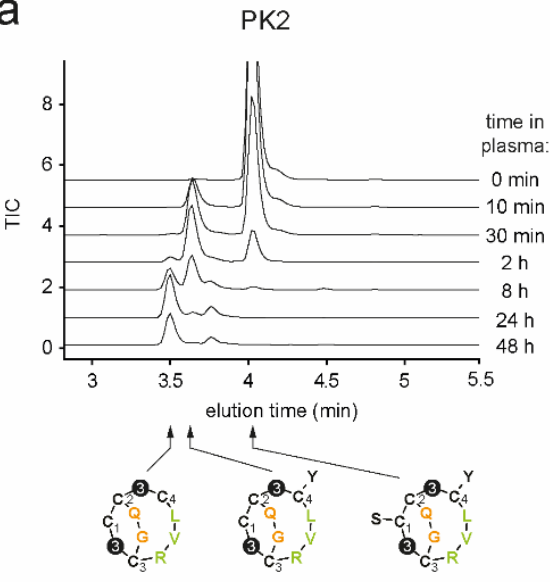

C

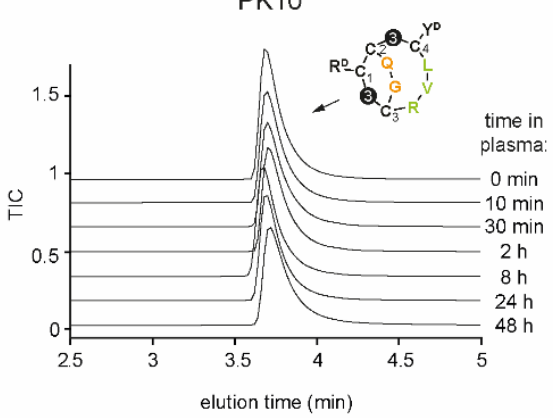

PK6
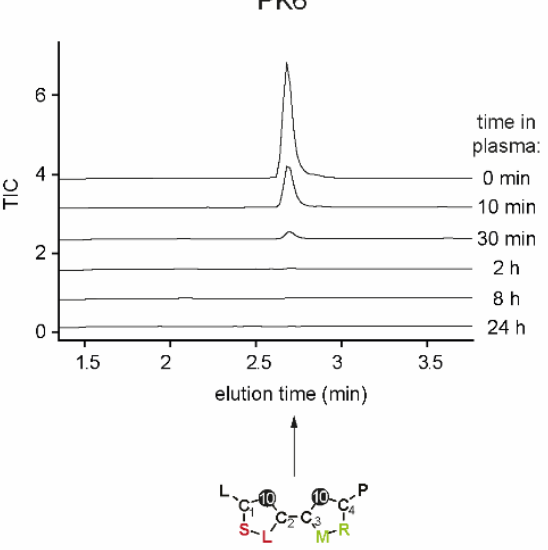

d

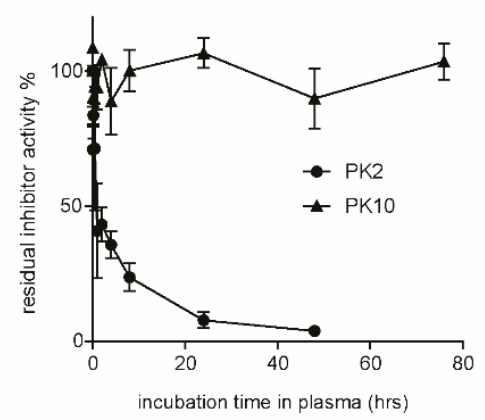

b

\begin{tabular}{ccc} 
Position & Mutation & \multicolumn{1}{c}{$K_{\mathrm{i}}(\mathrm{nM})$} \\
\hline \multirow{2}{*}{ Ser1 } & deletion & $2.1 \pm 0.5$ \\
& D-Ser & $1.1 \pm 0.3$ \\
& D-Thr & $1.4 \pm 0.0$ \\
& D-Arg & $0.6 \pm 0.1$ \\
& norArg & $3.7 \pm 0.4$ \\
& a-Methyl-Ser & $1.5 \pm 0.1$ \\
\hline \multirow{2}{*}{ Tyr11 } & deletion & $54 \pm 9.1$ \\
& D-Tyr & $5.6 \pm 0.9$ \\
& D-Phe & $12.2 \pm 4.1$ \\
& D-Trp & $12.1 \pm 4.6$ \\
& NMe-Tyr & $3.0 \pm 0.2$
\end{tabular}

e

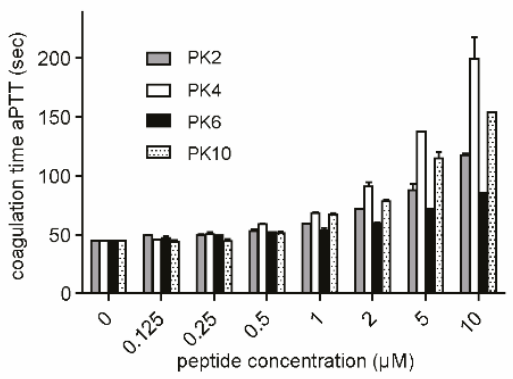


Figure 6

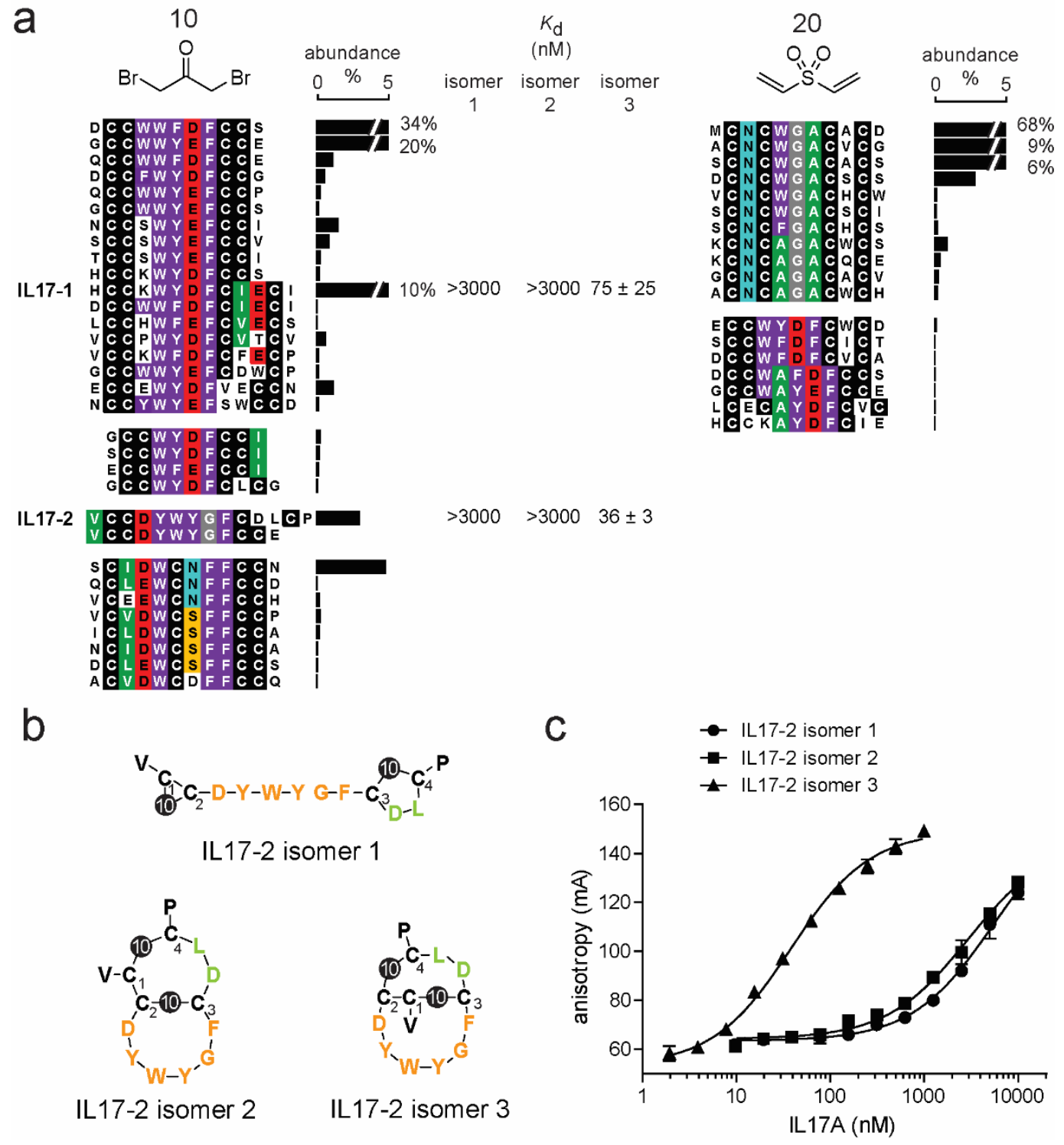




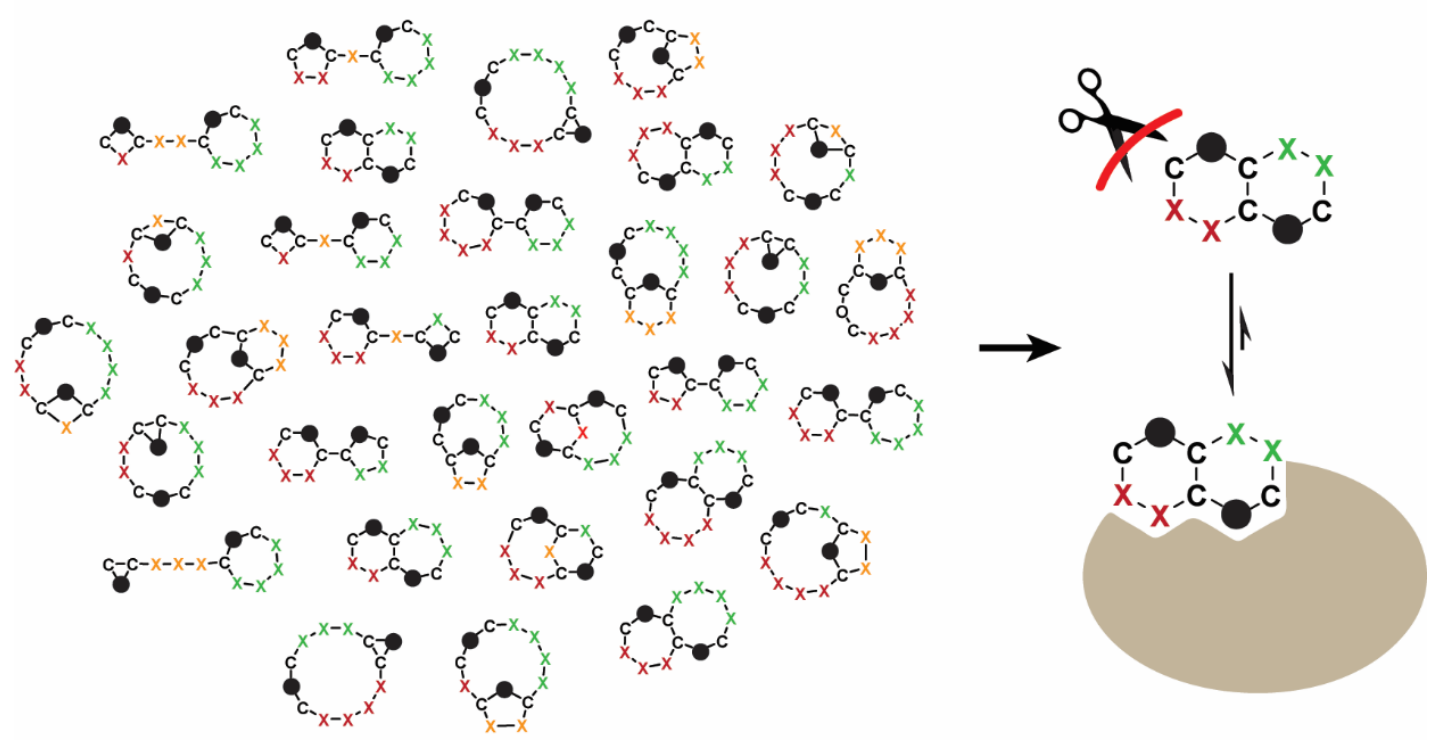




\section{Supplementary Information}

Cyclization of peptides with two chemical bridges affords large scaffold diversities

Sangram S. Kale ${ }^{1,2}$, Camille Villequey ${ }^{1,2}$, Xu-Dong Kong ${ }^{1,2}$, Alessandro Zorzi ${ }^{1}$, Kaycie Deyle ${ }^{1}$ and Christian Heinis ${ }^{1}$

${ }^{1}$ Institute of Chemical Sciences and Engineering, Ecole Polytechnique Fédérale de Lausanne (EPFL), $\mathrm{CH}-1015$ Lausanne, Switzerland

${ }^{2}$ The authors contributed equally to this work. 


\section{Index}

Supplementary Materials and Methods

Cyclization of model peptide with thiol-reactive reagents 4

$\begin{array}{ll}\text { Cloning of peptide libraries } & 4\end{array}$

$\begin{array}{ll}\text { Expression and purification of IL-17A } & 4\end{array}$

Phage selection of double-bridged peptides $\quad 5$

High-throughput DNA sequencing of enriched phage $\quad 6$

$\begin{array}{ll}\text { Peptide synthesis } & 6\end{array}$

$\begin{array}{ll}\text { Peptide cleavage and deprotection } & 7\end{array}$

$\begin{array}{ll}\text { Peptide cyclization by bridging random pairs of cysteines } & 7\end{array}$

$\begin{array}{ll}\text { Peptide cyclization by bridging specific pairs of cysteines } & 7\end{array}$

$\begin{array}{ll}\text { Peptide purification } & 8\end{array}$

Analysis of peptide purity and mass $\quad 8$

$\begin{array}{ll}\text { Protease inhibition assay } & 9\end{array}$

Plasma stability measurement by quantifying functional inhibitor 9

Plasma stability measurement by LC-MS analysis of bicyclic peptide $\quad 10$

$\begin{array}{lr}\text { aPTT and PT experiment } & 10\end{array}$

Measurement of peptide binding to IL-17A by fluorescence polarization 10

Supplementary Tables

Supplementary Table 1: Number of cysteines in peptides of plasma kallikrein selection 12

Supplementary Table 2: Number of cysteines in peptides of IL-17 selection 13

Supplementary Table 3: Molecular weight of peptides 14

Supplementary Figures

$\begin{array}{ll}\text { Supplementary Figure 1: Phage infectivity } & 17\end{array}$

Supplementary Figure 2: Peptide scaffolds in library 1 and $2 \quad 18$

Supplementary Figure 3: Abundance of peptide formats isolated from library $2 \quad 19$ 
$\begin{array}{ll}\text { Supplementary Figure 4: Consensus sequences } & 20\end{array}$

Supplementary Figure 5: Synthesis of individual regioisomers 22

Supplementary Figure 6: RP-HPLC chromatograms of double-bridged peptides 23

Supplementary Figure 7: Bicyclic peptide PK4 (isomer 3) variants 24

Supplementary Figure 8: Bicyclic peptide PK6 (isomer 1) variants 25

Supplementary Figure 9: Linker swapping 26

Supplementary Figure 10: Cyclization of peptides with linkers having similar structures 27

Supplementary Figure 11: Bicyclic peptide PK2 (isomer 3) variants 28

Supplementary Figure 12: Peptide formats in phage display library $3 \quad 29$

Supplementary Figure 13: Bicyclic peptide ligands of IL-17 30 


\section{Supplementary Materials and Methods}

Cyclization of model peptide with thiol-reactive reagents

$10 \mu \mathrm{l}$ of thiol-reactive reagents at concentrations ranging from $500 \mu \mathrm{M}$ to $32 \mathrm{mM}$ in acetonitrile (ACN) were added to $40 \mu \mathrm{l}$ of $50 \mu \mathrm{M}$ of the peptide ACSRCVECGWCG-NH $\mathrm{N}_{2}$ in $\mathrm{NH}_{4} \mathrm{CO}_{3}$ buffer $(60$ $\mathrm{mM}, \mathrm{pH} \mathrm{8.0)}$ and incubated for $1 \mathrm{hr}$ at $30^{\circ} \mathrm{C}$. For reagents 11 and 12, the peptides were dissolved in PBS buffer (100 mM, pH 6.4). All reagents were commercially available except for linker $\mathbf{7}$, which was synthesized as previously described ${ }^{39}$. Reactions were quenched with $40 \%$ formic acid $(10 \mu \mathrm{l})$ and analyzed by LC-MS (LCMS-2020, Shimadzu). Injection volume: $1 \mu \mathrm{l}$, column: Kinetix $\circledast \mathrm{C} 18,2.6 \mu \mathrm{m}, 100 \AA, 50 \times 2.1 \mathrm{~mm}$ (Phenomenex), gradient: solvent $\mathrm{A}\left(99.95 \% \mathrm{H}_{2} \mathrm{O}, 0.05 \%\right.$ formic acid) and $10-60 \%$ of solvent B (99.95\% ACN, $0.05 \%$ formic acid) over $5 \mathrm{~min}$, flow: $1 \mathrm{ml} \mathrm{min}{ }^{-}$ ${ }^{1}, \mathrm{MS}$ analysis: positive mode. Potential detrimental effects of the thiol-reactive reagents on phage were assessed by incubating $10^{11}$ phage (transforming units, t.u.) with the reagents and measuring the number of infective phage. $20 \mu \mathrm{l}$ of thiol-reactive reagents at concentrations ranging from 20 $\mu \mathrm{M}$ to $3 \mathrm{mM}$ in $\mathrm{ACN}$ were added to $80 \mu \mathrm{l}$ of $10^{11}$ t.u phage in $60 \mathrm{mM} \mathrm{NH}_{4} \mathrm{CO}_{3}$ buffer $\mathrm{pH} 8.0$, and incubated for $1 \mathrm{hr}$ at $30^{\circ} \mathrm{C}$. The number of functional phage was quantified by infecting $20 \mu \mathrm{l}$ of exponentially growing $E$. coli cells with 10 -fold dilutions of the phage and plating the cells on selective agar plates $\left(30 \mu \mathrm{g} \mathrm{ml}^{-1}\right.$ chloramphenicol).

\section{Cloning of peptide libraries}

Phage display library 3 was cloned using 155 degenerate DNA primers that each contained codons for four cysteines in different positions and 5-10 random amino acids (NNK codons). The library was cloned based on an fd-tet phage vector. Electroporation of the DNA into TG1 E. coli cells yielded $>2 \times 10^{10}$ colonies on tetracycline-selective plates.

\section{Expression and purification of IL-17A}

DNA encoding the mature form of human IL-17A (Gly24-Ala155) was cloned into pEXPR for the expression of poly-histidine tagged IL-17A in mammalian cells as a secreted protein. The protein was expressed by transient transfection of $\mathrm{CHO}$ cells cultured in solution, and IL-17A was purified from the culture supernatant by Ni-NTA affinity chromatography. Eluted protein was further purified by size-exclusion chromatography on a Superdex75 column with PBS buffer (10 $\mathrm{mM} \mathrm{Na}_{2} \mathrm{HPO}_{4}$, $1.8 \mathrm{mM} \mathrm{KH}_{2} \mathrm{PO}_{4}, \mathrm{pH}$ 7.4, $137 \mathrm{mM} \mathrm{NaCl}, 2.7 \mathrm{mM} \mathrm{KCl}$ ). 


\section{Phage selection of double-bridged peptides}

Phage of the libraries produced in separate $1 \mathrm{~L}$ E. coli cultures were pooled, purified by PEGprecipitation, and the cysteines in the peptides reduced as previously described ${ }^{40}$. Phage were dissolved in $50 \mathrm{ml}$ aqueous buffer containing $20 \mathrm{mM} \mathrm{NH}_{4} \mathrm{CO}_{3}, 5 \mathrm{mM}$ EDTA, pH 8 and distributed into six tubes. The peptides were chemically modified by adding $2 \mathrm{ml}$ of the cyclization reagents in $\mathrm{ACN}$ to $8 \mathrm{ml}$ phage, and incubating for $1 \mathrm{hr}$ at $30{ }^{\circ} \mathrm{C}$ in a water bath. Modified phage were precipitated in 20\% PEG, $500 \mathrm{mM} \mathrm{NaCl}$, and dissolved in $3 \mathrm{ml}$ washing buffer (10 mM Tris- $\mathrm{Cl}$, pH 7.4, $150 \mathrm{mM} \mathrm{NaCl}, 10 \mathrm{mM} \mathrm{MgCl}_{2}, 1 \mathrm{mM} \mathrm{CaCl}_{2}, \mathrm{pH}$ 7.4). Human plasma kallikrein (Molecular Innovations) and the recombinantly expressed IL-17A were biotinylated by incubating the proteins at a concentration of $10 \mu \mathrm{M}$ with a 15-fold molar excess of EZ-Link ${ }^{\mathrm{TM}}$ Sulfo-NHS-LC-Biotin (ThermoFisher Scientific) for $1 \mathrm{hr}$ at RT, and the excess biotinylation reagent was removed by size exclusion chromatography. $2.5 \mu \mathrm{g}$ of biotinylated target protein was incubated with $50 \mu \mathrm{l}$ magnetic streptavidin beads (Dynabeads ${ }^{\circledR}$ M-280 Streptavidin, ThermoFisher Scientific) in $500 \mu$ of washing buffer for 15 minutes and non-immobilized protein was removed by washing three times. Both phage and the beads were separately blocked by the addition of $500 \mu$ of washing buffer containing $1 \% \mathrm{w} / \mathrm{v}$ BSA and $0.1 \% \mathrm{v} / \mathrm{v}$ Tween 20 , and incubated for 30 minutes. Phage and magnetic beads were mixed and incubated for $1 \mathrm{hr}$ on a rotating wheel at RT. The beads were washed eight times with washing buffer containing $0.1 \% \mathrm{v} / \mathrm{v}$ Tween 20 and twice with washing buffer only. Phage were eluted by incubating the beads with $100 \mu \mathrm{l}$ of $50 \mathrm{mM}$ glycine, $\mathrm{pH} 2.2$ for $5 \mathrm{~min}$. The solution containing the eluted phage was neutralized by the addition of $50 \mu \mathrm{l} 1 \mathrm{M}$ Tris$\mathrm{Cl}, \mathrm{pH} 8.0$ and added to $30 \mathrm{ml}$ of exponentially growing TG1 E. coli cells $\left(\mathrm{OD}_{600}=0.4\right)$. After a 90 min incubation, the freshly infected bacteria were plated on 2YT/chloramphenicol plates (30 $\mu \mathrm{g}$ $\mathrm{ml}^{-1}$ ) and incubated overnight at $37^{\circ} \mathrm{C}$. Bacterial cells of the colonies were recovered the next day in a small volume of 2 YT media and stored as glycerol stocks at $-80^{\circ} \mathrm{C}$. The second round of selection was performed using neutravidin-coated magnetic beads to prevent the enrichment of streptavidin-specific peptides. Neutravidin beads were generated by coupling neutravidin to tosylactivated magnetic beads according to the manufacturer's recommended protocol (Dynabeads M280 Tosylactivated, Invitrogen Dynal Biotech AS). 
High-throughput DNA sequencing of enriched phage

Phage DNA was extracted from E. coli cell pellets (around $50 \mathrm{mg}$ ) using a kit wherein the DNA was eluted with $5 \mathrm{mM}$ Tris- $\mathrm{HCl}, \mathrm{pH}$ 8.5. The DNA region encoding the peptides was amplified by PCR using 100 ng phage DNA as template, one of the following forward primers, and the reverse primer 5'-CCTCTCTATGGGCAGTCGGTGATTTTCAACAGTTTCAGCGGAGTG-3'. Each primer contains a sequence for annealing to the phage vector (italics) and an adapter sequence for ion semiconductor sequencing. The forward primers contain a barcode that encodes the cyclization reagent used in the phage selection (underlined), allowing for pooled sequencing of all isolated phage and deconvolution.

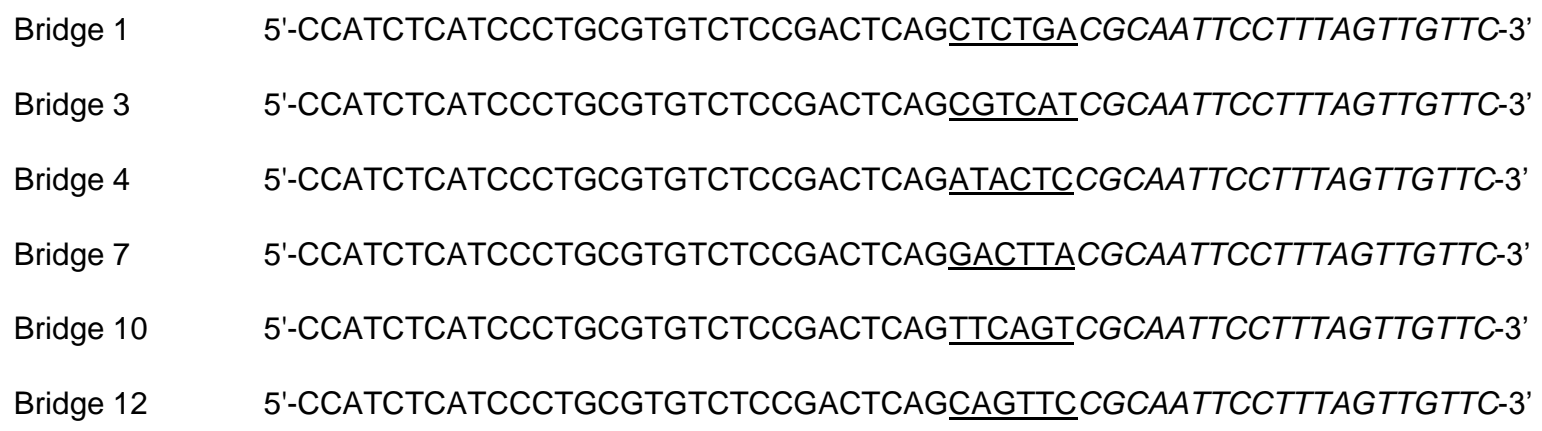

A standard PCR reaction was performed $\left(25\right.$ cycles, $30 \mathrm{~s} 95^{\circ} \mathrm{C}, 30 \mathrm{~s} 55^{\circ} \mathrm{C}, 30 \mathrm{~s} 72^{\circ} \mathrm{C}$ ) in a volume of $50 \mu \mathrm{l}$ containing Taq polymerase buffer, $250 \mu \mathrm{M}$ dNTP, $500 \mathrm{nM}$ primer, and 1 unit Taq polymerase. Three additional PCR cycles were performed with fresh reagents wherein $10 \mu \mathrm{l}$ of the first PCR reaction served as a template in order to limit the amount of DNA heteroduplex. PCR products were separated by agarose gel electrophoresis (2.5\% gel UltraPure agarose, Invitrogen), extracted using a kit, and DNA was elution with $5 \mathrm{mM}$ Tris $-\mathrm{HCl}, \mathrm{pH}$ 8.5. Ion semiconductor sequencing was performed by the Centre for Research in Agricultural Genomics (Barcelona, Spain) on an Ion Personal Genome Machine (PGM ${ }^{T M}$ ) sequencer. Sequence data was processed and sequences were aligned using Matlab scripts ${ }^{41}$.

\section{Peptide synthesis}

Peptides were synthesized on an Advanced ChemTech $348 \Omega$ parallel peptide synthesizer (AAPPTec) by standard Fmoc solid-phase chemistry on Rink Amide MBHA resin $(0.26 \mathrm{mmol} / \mathrm{g}$ resin, $0.03 \mathrm{mmol}$ scale). The coupling was carried out twice for each natural amino acid (4 eq.) 
using HBTU (4 eq.), HOBt (4 eq.) and DIEA (6 eq.) in $1.3 \mathrm{ml} \mathrm{DMF} \mathrm{with} \mathrm{shaking} \mathrm{at} 400 \mathrm{rpm}$ for 30 min. The coupling of unnatural amino acids (2 eq.) was performed once using HATU (2 eq.) and DIEA (4 eq.) in $1.5 \mathrm{ml} \mathrm{DMF}$ and shaking at $400 \mathrm{rpm}$ for $1 \mathrm{hr}$. Fmoc groups were removed by incubating the resin twice with $20 \% \mathrm{v} / \mathrm{v}$ piperidine in DMF with shaking $400 \mathrm{rpm}$ for $5 \mathrm{~min}$. Washing steps were performed with $3 \mathrm{ml}$ DMF. The resin was washed four times before Fmoc removal and five times after Fmoc removal.

\section{Peptide cleavage and deprotection}

Final peptides were deprotected and cleaved from the resin under reducing conditions by incubation in $90 \%$ TFA, 2.5\% $\mathrm{H}_{2} \mathrm{O}, 2.5 \%$ thioanisole, 2.5\% phenol, 2.5\% EDT with shaking for 4 hrs at room temperature. The resin was removed by vacuum filtration, peptides precipitated with cold diethyl ether $(50 \mathrm{ml})$ and a $30 \mathrm{~min}$ incubation at $-20^{\circ} \mathrm{C}$, and pelleted by centrifugation at 4400 $\mathrm{g}$ for $5 \mathrm{~min}$. The peptide pellets were washed twice with cold diethyl ether $(30 \mathrm{ml})$ and lyophilized or directly purified by HPLC.

Peptide cyclization by bridging random pairs of cysteines

Purified peptide ( $9 \mathrm{ml}, 1.2 \mathrm{mM}$ ) was dissolved in $40 \% \mathrm{v} / \mathrm{v} \mathrm{ACN}$ and $60 \% \mathrm{v} / \mathrm{v}$ aqueous buffer (60 $\mathrm{mM} \mathrm{NH}_{4} \mathrm{HCO}_{3}, \mathrm{pH} 8.0$ ) and the cyclization reagent was added ( $1 \mathrm{ml}, 40 \mathrm{mM}$ in $\mathrm{ACN}$ ). The final reagent and solvent concentrations in the reaction mixture were $1 \mathrm{mM}$ peptide, $4 \mathrm{mM}$ cyclization reagent, $50 \% \mathrm{v} / \mathrm{v}$ aqueous buffer, and $50 \% \mathrm{v} / \mathrm{v} \mathrm{ACN}$. The reaction mixture was incubated at $30^{\circ} \mathrm{C}$ in a water bath for $1 \mathrm{hr}$ and then lyophilized.

\section{Peptide cyclization by bridging specific pairs of cysteines}

Peptides with defined pairs of cysteines bridged by chemical linkers were synthesized as shown in Supplementary Fig. 5 and described in the following. Peptides were synthesized on Rink amide resin as described above wherein the $\mathrm{N}$-terminal Fmoc group was not removed. Two of the cysteines were protected at the side chain with Mmt and two with Dpm. After washing the resin with $5 \mathrm{ml} \mathrm{DCM}$, the two cysteines with the Mmt groups were removed by shaking the resin in $5 \mathrm{ml}$ of TFA:TIS:DCM (1:5:94) in a fritted syringe for $3 \mathrm{~min}$. The solution was removed and the deprotection repeated 9 times. The resin was washed 3 times with DCM for 1 min and swollen by washing 4 times with DMF. 2 eq. of cyclization reagent in $3 \mathrm{ml} \mathrm{DMF}$ and 4 eq. of DIPEA in $1 \mathrm{ml}$ 
were added together stepwise and the reaction was shaken for $1 \mathrm{hr}$ at $\mathrm{RT}$. The reaction solution was removed and the resin was washed 4 times with DMF. The Fmoc group at the N-terminal amine was removed by adding twice $3 \mathrm{ml}$ of $20 \%$ piperidine in DMF for $5 \mathrm{~min}$ and shaking. The resin was washed 4 times with DMF and subjected to global deprotection in $5 \mathrm{ml}$ of the cleavage mixture TFA:TIS:EDT: $\mathrm{H}_{2} \mathrm{O}$ (97:1:1:2) for $12 \mathrm{hrs}$. In the case of linker 10 EDT was avoided in the cleavage mixture because of a reaction of EDT with the ketone group. The resin was filtered and peptide was precipitated by addition of $45 \mathrm{ml}$ cold ether and incubation at $-20^{\circ} \mathrm{C}$ for $20 \mathrm{~min}$. The peptide was pelleted by centrifugation at $4400 \mathrm{~g}$ for $5 \mathrm{~min}$, washed twice with $30 \mathrm{ml}$ ether and lyophilized. The crude peptide was dissolved in around $2 \mathrm{ml}$ in a $1: 1$ mixture of $\mathrm{H}_{2} \mathrm{O}$ and $\mathrm{ACN}$ to reach a concentration of $10 \mathrm{mM}$. 1.5 eq of cyclization reagent in $5 \mathrm{ml} \mathrm{ACN}$ and $9 \mathrm{ml}$ of $60 \mathrm{mM}$ $\mathrm{NH}_{4} \mathrm{HCO}_{3} \mathrm{pH} 8$ were added stepwise. If the solution was turbid, $4 \mathrm{ml}$ of ACN were added. The reaction was incubated at $30^{\circ} \mathrm{C}$ for $1 \mathrm{hr}$. The reaction was quenched by the addition of $1 \mathrm{ml}$ of $40 \% \mathrm{HCOOH}$. The peptide was lyophilized and purified by RP-HPLC.

\section{Peptide purification}

Peptides were purified with a HPLC system (Prep LC 2535 HPLC, Waters) using a preparative C18 reversed-phase column (Sunfire ${ }^{\mathrm{TM}}$ prep C18 OBD $10 \mu \mathrm{m}, 100 \AA$, 19x250 mm, Waters) or a semi-preparative C18 reversed-phase column (X-bridge peptide BEH C18 $5 \mu \mathrm{m}, 300 \AA$, 10x250 $\mathrm{mm}$, Waters) applying a flow rate of 20 or $6 \mathrm{ml} \mathrm{min}^{-1}$ and a linear gradient of $10-50 \% \mathrm{v} / \mathrm{v}$ solvent $\mathrm{B}$ in $40 \mathrm{~min}\left(\mathrm{~A}: 99.9 \% \mathrm{v} / \mathrm{v} \mathrm{H}_{2} \mathrm{O}\right.$ and $0.1 \% \mathrm{v} / \mathrm{v}$ TFA; $\mathrm{B}: 99.9 \% \mathrm{v} / \mathrm{v} \mathrm{ACN}$ and $0.1 \% \mathrm{v} / \mathrm{v}$ TFA). Fractions containing the desired peptide were lyophilized.

\section{Analysis of peptide purity and mass}

The purity was assessed by analyzing around $10 \mu \mathrm{g}$ of peptide by RP-HPLC (1260 HPLC system, Agilent) using a C18 column (ZORBAX 300SB-C18, $5 \mu \mathrm{m}, 300 \AA$ A 4.6x250 mm, Agilent). Peptides were run at a flow rate of $1 \mathrm{ml} \mathrm{min} \mathrm{m}^{-1}$ with a linear gradient of $0-100 \%$ or $0-50 \% \mathrm{v} / \mathrm{v}$ of solvent $\mathrm{B}$ over $15 \mathrm{~min}\left(\mathrm{~A}: 94.9 \% \mathrm{v} / \mathrm{v} \mathrm{H} \mathrm{H}_{2} \mathrm{O}, 5 \% \mathrm{v} / \mathrm{v} \mathrm{ACN}\right.$ and $0.1 \% \mathrm{v} / \mathrm{v}$ TFA; $\mathrm{B}: 94.9 \% \mathrm{v} / \mathrm{v} \mathrm{ACN}, 5 \% \mathrm{v} / \mathrm{v} \mathrm{H}_{2} \mathrm{O}$ and $0.1 \% \mathrm{v} / \mathrm{v}$ TFA). The mass of purified peptides was determined by electrospray ionization mass spectrometry (ESI-MS) in positive ion mode on a single quadrupole liquid chromatography mass spectrometer (LCMS-2020, Shimadzu). The theoretical and observed masses of all peptides are shown in Supplementary Table 3. 


\section{Protease inhibition assay}

Inhibition constants $\left(K_{\mathrm{i}}\right)$ were determined by measuring the residual activities of protease in the presence of different dilutions of inhibitor (2-fold dilutions, ranging from $3 \mu \mathrm{M}$ to $0.2 \mathrm{nM}$ final concentration) using fluorogenic substrates. Activities were measured at $25^{\circ} \mathrm{C}$ in buffer containing $10 \mathrm{mM}$ Tris-Cl, $\mathrm{pH}$ 7.4, $150 \mathrm{mM} \mathrm{NaCl}, 10 \mathrm{mM} \mathrm{MgCl}_{2}, 1 \mathrm{mM} \mathrm{CaCl}_{2}, 0.1 \% \mathrm{w} / \mathrm{v} \mathrm{BSA}$ and $0.01 \% \mathrm{v} / \mathrm{v}$ Triton-X100 by monitoring the change in fluorescence intensity over one hour using a Tecan infinite M200 Pro plate reader (excitation at $367 \mathrm{~nm}$, emission recorded at $468 \mathrm{~nm}$ ). All proteases were human in origin and were purchased from Molecular Innovations or Innovative Research and the following concentrations were used: $0.1 \mathrm{nM}$ plasma kallikrein, $0.25 \mathrm{nM}$ factor Xla, $2 \mathrm{nM}$ factor XIla, $2 \mathrm{nM}$ thrombin, $1.5 \mathrm{nM}$ uPA, $7.5 \mathrm{nM}$ tPA, $2.5 \mathrm{nM}$ plasmin, $6 \mathrm{nM}$ factor Xa, $50 \mathrm{nM}$ factor VIla. The following fluorogenic substrates were used at $50 \mu \mathrm{M}$ final concentration: Z-Phe-Arg-AMC for plasma kallikrein, Boc-Phe-Ser-Arg-AMC for factor XIa, Boc-GIn-Gly-Arg-AMC for factor XIla, ZGly-Gly-Arg-AMC for thrombin, uPA and tPA, H-D-Val-Leu-Lys-AMC for plasmin, D-Phe-Pro-ArgANSNH-C4H9 for factor $\mathrm{Xa}$ and factor VIla. The $I C_{50}$ values were determined by fitting sigmoidal curves to the data using the following four-parameter logistic equation used for dose response curves:

$$
y=\frac{100}{1+10^{\left(\log I C_{50}-x\right) p}}
$$

The $K_{\mathrm{i}}$ values were calculated based on the $I C_{50} \mathrm{~S}$ using the Cheng-Prusoff equation.

\section{Plasma stability measurement by quantifying functional inhibitor}

$20 \mu \mathrm{M}$ of peptide was incubated in human plasma (Innovative Research) at $37^{\circ} \mathrm{C}$ in a water bath and $30 \mu \mathrm{l}$ probes were taken at different time points ( $5 \mathrm{~min}, 0.5,1,2,4,8,24$, and $48 \mathrm{hrs}$ ). The samples were diluted by addition of $770 \mu$ assay buffer containing $0.1 \%(\mathrm{w} / \mathrm{v}) \mathrm{BSA}$ and $0.01 \%$ $(\mathrm{v} / \mathrm{v})$ Triton-X100 and the proteases were heat-inactivated by incubation at $69^{\circ} \mathrm{C}$ for $20 \mathrm{~min}$. The samples were stored at $-20^{\circ} \mathrm{C}$. Residual inhibitor activity was measured using the protease activity assay described above. The samples were centrifuged at $16,000 \mathrm{~g}$ for $5 \mathrm{~min}$ and the supernatant was transferred to new tubes. Two-fold dilutions of the samples were prepared and the residual activity of $0.1 \mathrm{nM}$ human plasma kallikrein was measured with $50 \mu \mathrm{M}$ Z-Phe-Arg-AMC substrate as described above. Residual inhibition in \% was calculated using the equation $I C_{50,0 \mathrm{~h}} / I_{50, \mathrm{xh}}{ }^{*} 100$ wherein $I C_{50,0 \mathrm{~h}}$ is the functional strength of the inhibitor at time point 0 and $I C_{50, x h}$ the functional strength of inhibitor after one of the different plasma incubation periods mentioned above. The 
resulting percentages of inhibition were plotted versus time and analyzed using a one-phase exponential decay model.

Plasma stability measurement by LC-MS analysis of bicyclic peptide

$40 \mu \mathrm{M}$ of peptide was incubated in human plasma (Innovative Research) at $37^{\circ} \mathrm{C}$ in a water bath. $5 \mu \mathrm{l}$ probes were taken at different time points ( $5 \mathrm{~min}, 0.5,1,2,4,8,24$, and $48 \mathrm{hrs}$ ), diluted by addition of $5 \mu \mathrm{l} 6 \mathrm{M}$ guanidine hydrochloride $\mathrm{pH} 2$ and incubated at room temperature for $30 \mathrm{~min}$. The plasma proteins were precipitated by addition of cold ethanol $(200 \mu \mathrm{l})$ and incubated for 30 $\min$ at $-20^{\circ} \mathrm{C}$. The samples were centrifuged at $9000 \mathrm{~g}$ for $20 \mathrm{~min}$, the supernatant was transferred to new tubes and the solvent was evaporated under vacuum (speed vac). The samples were dissolved in $20 \mu$ of $\mathrm{H}_{2} \mathrm{O}$ and analyzed by LC-MS as described above.

\section{aPTT and PT experiment}

aPTT was determined in human plasma using a STAGO STart4 Coagulation analyzer (Diagnostica). Human single donor plasma was used (Innovative Research). $100 \mu$ l of plasma was incubated with $100 \mu \mathrm{l}$ of Pathromtin* SL (silicon dioxide particles, plant phospholipids in HEPES buffer system, Siemens) for $2 \mathrm{~min}$ at $37^{\circ} \mathrm{C}$. The coagulation was triggered by addition of $100 \mu \mathrm{l}$ $\mathrm{CaCl}_{2}$ solution (25 mM, Siemens). Upon addition of this reagent the electromagnetically induced movement of a steel ball in the plasma was monitored. The time until the ball stopped moving was recorded as coagulation time.

\section{Measurement of peptide binding to IL-17A by fluorescence polarization}

IL-17A was serially diluted (twofold) in PBS containing $0.01 \% \mathrm{v} / \mathrm{v}$ Tween-20. $45 \mu$ l of the dilutions were added to $15 \mu \mathrm{l}$ of fluorescent peptide $(20 \mathrm{nM})$ in black 96 -well, half-area microtiter plates. Fluorescence anisotropy was measured with an Infinite M200Pro plate reader (Tecan) using an excitation filter at $485 \mathrm{~nm}$ and an emission filter at $535 \mathrm{~nm}$. Dissociation constants $\left(K_{\mathrm{d}}\right)$ were determined by nonlinear regression analysis of anisotropy versus the total concentration of proteins $[P]_{T}$ using the following equation: 


$$
A=A_{f}+\left(A_{b}-A_{f}\right) \times\left\{\frac{[L]_{T}+K_{D}+[P]_{T}-\sqrt{\left([L]_{T}+K_{D}+[P]_{T}\right)^{2}-4[L]_{T}[P]_{T}}}{2[L]_{T}}\right\}
$$

$A$ is the experimentally determined fluorescence anisotropy. $A_{f}$ and $A_{b}$ are the fluorescence anisotropy for the free and the fully bound fluorescent ligand, respectively. $\left[\mathrm{L}_{T}\right.$ and $[\mathrm{P}]_{T}$ represent the total fluorescent ligand and protein concentration, respectively. $K_{\mathrm{D}}$ is the dissociation constant for the binding equilibrium. Values were calculated with Prism 5 (GraphPad software). 


\section{Supplementary Tables}

Supplementary Table 1 Number of cysteines in peptides. The percentage of different peptides isolated from library 1 and 2 after two and three rounds of selection against plasma kallikrein are indicated. Data is provided for the selections performed with different linkers. Peptides containing four cysteines were enriched in all selections except the one performed with linker 12.

\begin{tabular}{|c|c|c|c|c|c|c|c|}
\hline \multirow{2}{*}{ selection } & \multirow{2}{*}{ \# cysteines } & \multicolumn{6}{|c|}{$\%$ peptides } \\
\hline & & linker 1 & linker 3 & linker 4 & linker 7 & linker 10 & linker 12 \\
\hline \multirow{5}{*}{ round 2} & 0 & 1 & 1 & 0 & 1 & 1 & 1 \\
\hline & 1 & 6 & 4 & 3 & 3 & 4 & 4 \\
\hline & 2 & 24 & 15 & 13 & 11 & 20 & 8 \\
\hline & 3 & 26 & 37 & 13 & 18 & 34 & 66 \\
\hline & 4 & 43 & 44 & 70 & 66 & 41 & 22 \\
\hline \multirow{5}{*}{ round 3} & 0 & 3 & 2 & 1 & 2 & 3 & 1 \\
\hline & 1 & 8 & 6 & 7 & 9 & 10 & 7 \\
\hline & 2 & 10 & 17 & 14 & 17 & 26 & 13 \\
\hline & 3 & 15 & 21 & 11 & 17 & 18 & 54 \\
\hline & 4 & 63 & 53 & 66 & 53 & 42 & 25 \\
\hline
\end{tabular}


Supplementary Table 2 Number of cysteines in peptides. The percentage of different peptides isolated from library 3 after three rounds of selection against IL-17 are indicated.

\begin{tabular}{|c|c|c|c|}
\hline selection & \# cysteines & \multicolumn{2}{|c|}{ \% peptides } \\
\hline & & linker 10 & linker 20 \\
\hline \multirow{7}{*}{ round 3 } & 0 & 0 & 0 \\
\cline { 2 - 4 } & 1 & 0.1 & 0 \\
\cline { 2 - 4 } & 2 & 0.8 & 0.3 \\
\cline { 2 - 4 } & 3 & 5.3 & 0.7 \\
\cline { 2 - 4 } & 4 & 91 & 96.7 \\
\cline { 2 - 4 } & $>4$ & 2.7 & 2.3 \\
\hline
\end{tabular}


Supplementary Table 3 Molecular weight of peptides. For the peptides PK1-PK10, the observed and calculated molecular weight are indicated for the most active isomer that was purified.

\begin{tabular}{|c|c|c|c|}
\hline peptide & observed $[\mathrm{M}+2 \mathrm{H}]^{2+}$ & calculated MW & theoretical MW \\
\hline PK1 & 690.22 & 1378.44 & 1378.78 \\
\hline PK2 & 719.80 & 1437.60 & 1437.50 \\
\hline PK3 & 697.86 & 1393.72 & 1393.82 \\
\hline PK4 & 740.90 & 1479.80 & 1479.66 \\
\hline PK5 & 685.23 & 1368.46 & 1368.46 \\
\hline PK6 & 618.70 & 1235.40 & 1235.56 \\
\hline PK7 & 596.75 & 1191.50 & 1190.80 \\
\hline PK8 & 649.20 & 1296.40 & 1297.16 \\
\hline PK9 & 671.54 & 1341.08 & 1341.30 \\
\hline PK10 & 754.35 & 1506.70 & 1506.60 \\
\hline PK4 (isomer 1) & 740.80 & 1479.60 & 1479.66 \\
\hline PK4 (isomer 2) & 740.90 & 1479.80 & 1479.66 \\
\hline PK4 (isomer 3) & 740.90 & 1479.80 & 1479.66 \\
\hline PK6 (isomer 1) & 618.70 & 1235.40 & 1235.56 \\
\hline PK6 (isomer 2) & 619.00 & 1236.00 & 1235.56 \\
\hline PK6 (isomer 3) & 618.50 & 1235.00 & 1235.56 \\
\hline PK4-3-3 & 740.90 & 1479.80 & 1479.66 \\
\hline PK4-3-1 & 740.60 & 1479.20 & 1479.66 \\
\hline PK4-3-2 & 740.85 & 1479.70 & 1479.66 \\
\hline PK4-3-5 & 715.85 & 1429.70 & 1429.66 \\
\hline PK4-3-10 & 716.80 & 1431.60 & 1431.66 \\
\hline PK4-1-3 & 740.85 & 1479.70 & 1479.66 \\
\hline PK4-2-3 & 740.90 & 1479.80 & 1479.66 \\
\hline PK4-5-3 & 715.85 & 1429.70 & 1429.66 \\
\hline PK4-10-3 & 716.80 & 1431.60 & 1431.66 \\
\hline
\end{tabular}




\begin{tabular}{|c|c|c|c|}
\hline PK6-10-10 & 618.70 & 1235.40 & 1235.56 \\
\hline PK6-10-1 & 642.75 & 1283.50 & 1283.60 \\
\hline PK6-10-3 & 642.70 & 1283.40 & 1283.60 \\
\hline PK6-10-2 & 642.75 & 1283.50 & 1283.60 \\
\hline PK6-10-5 & 617.65 & 1233.30 & 1233.58 \\
\hline PK6-1-10 & 642.75 & 1283.50 & 1283.60 \\
\hline PK6-3-10 & 642.75 & 1283.50 & 1283.60 \\
\hline PK6-2-10 & 642.75 & 1283.50 & 1283.60 \\
\hline PK6-5-10 & 617.50 & 1233.00 & 1233.58 \\
\hline PK2 Ser1Ala & 711.85 & 1421.70 & 1421.53 \\
\hline PK2 Ser1Thr & 726.80 & 1451.60 & 1451.50 \\
\hline PK2 Ser1Gly & 704.75 & 1407.50 & 1407.47 \\
\hline PK2 GIn4Leu & 712.35 & 1422.70 & 1422.50 \\
\hline PK2 Gln4Arg & 733.80 & 1465.60 & 1465.53 \\
\hline PK2 Gln4Ala & 691.10 & 1380.20 & 1380.54 \\
\hline PK2 GIn4Ser & 699.30 & 1396.60 & 1396.45 \\
\hline PK2 Gly5Ala & 726.90 & 1451.80 & 1451.53 \\
\hline PK2 Gly5Thr & 741.80 & 1481.60 & 1481.50 \\
\hline PK2 Gly5Val & 740.85 & 1479.70 & 1479.60 \\
\hline PK2 Val8Ala & 705.80 & 1409.60 & 1409.45 \\
\hline PK2 Val8Thr & 720.80 & 1439.60 & 1439.47 \\
\hline PK2 Leu9lle & 719.80 & 1437.60 & 1437.53 \\
\hline PK2 Leu9GIn & 727.30 & 1452.60 & 1452.47 \\
\hline PK2 Leu9Asn & 720.30 & 1438.60 & 1438.44 \\
\hline PK2 Leu9Ala & 698.85 & 1395.70 & 1395.42 \\
\hline PK2 Leu9Ser & 706.75 & 1411.50 & 1411.42 \\
\hline PK2 Leu9Gly & 691.75 & 1381.50 & 1381.39 \\
\hline PK2 Leu9Val & 712.85 & 1423.70 & 1423.47 \\
\hline PK2 Tyr11Ala & 673.80 & 1345.60 & 1345.45 \\
\hline
\end{tabular}




\begin{tabular}{|c|c|c|c|}
\hline PK2 Tyr11Trp & 731.35 & 1460.70 & 1460.53 \\
\hline PK2 Tyr11Phe & 711.90 & 1421.80 & 1421.50 \\
\hline PK2 Tyr11Leu & 694.85 & 1387.70 & 1387.48 \\
\hline PK2 Tyr11lle & 694.80 & 1387.60 & 1387.48 \\
\hline PK2 Gln4Asn & 712.80 & 1423.60 & 1423.47 \\
\hline PK2 Gln4Lys & 719.85 & 1437.70 & 1437.54 \\
\hline PK2 Gln4Phe & 729.35 & 1456.70 & 1456.54 \\
\hline PK2 Ser1 deletion & 676.00 & 1350.00 & 1350.45 \\
\hline PK2 Tyr11 deletion & 638.20 & 1274.40 & 1274.35 \\
\hline PK2 Tyr11D-Tyr & 719.85 & 1437.70 & 1437.53 \\
\hline PK2 Tyr11D-Phe & 711.85 & 1421.70 & 1421.50 \\
\hline PK2 Tyr11D-Trp & 731.40 & 1460.80 & 1460.53 \\
\hline PK2 Ser1D-Arg & 754.30 & 1506.60 & 1506.60 \\
\hline PK2 Ser1D-Ser & 719.75 & 1437.50 & 1437.54 \\
\hline PK2 Ser1D-Thr & 726.90 & 1451.80 & 1451.53 \\
\hline PK2 Tyr11N-MeTyr & 727.00 & 1452.00 & 1451.54 \\
\hline PK2 Ser1norArg & 747.35 & 1492.70 & 1492.60 \\
\hline PK2 Ser1aMe-Ser & 726.65 & 1451.30 & 1451.54 \\
\hline IL17-1 (isomer 1) & 1065.05 & 2128.10 & 2128.47 \\
\hline IL17-1 (isomer 2) & 1065.05 & 2128.10 & 2128.47 \\
\hline IL17-1 (isomer 3) & 1065.05 & 2128.10 & 2128.47 \\
\hline IL17-2 (isomer 1) & 1077.00 & 2152.00 & 2152.44 \\
\hline IL17-2 (isomer 2) & 1076.95 & 2151.90 & 2152.44 \\
\hline IL17-2 (isomer 3) & 1076.90 & 2151.80 & 2152.44 \\
\hline
\end{tabular}




\section{Supplementary Figures}

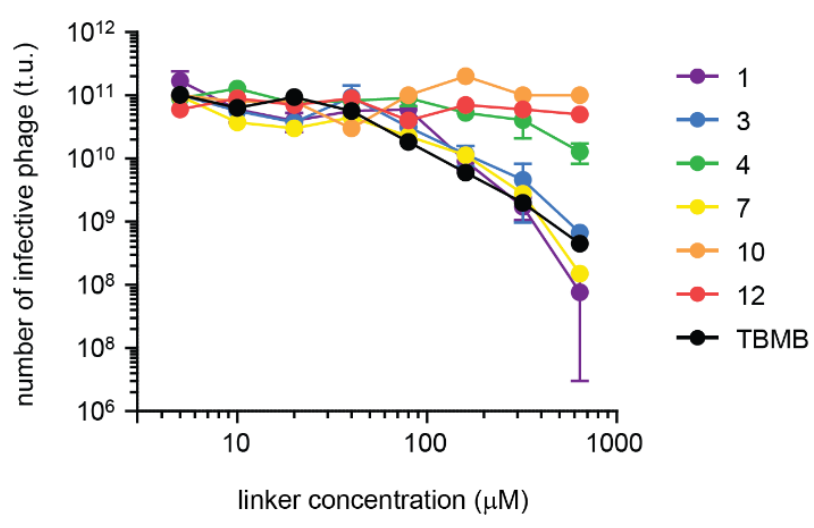

Supplementary Figure 1 Phage infectivity. $10^{11}$ t.u. of phage from library 1 were incubated with different concentrations of the linkers in $80 \%$ aqueous buffer $\left(20 \mathrm{mM} \mathrm{NH}_{4} \mathrm{HCO}_{3}, \mathrm{pH}\right.$ ) and $20 \%$ $\mathrm{ACN}$ for $1 \mathrm{hr}$ and the number of infective phages was determined. 
library 1
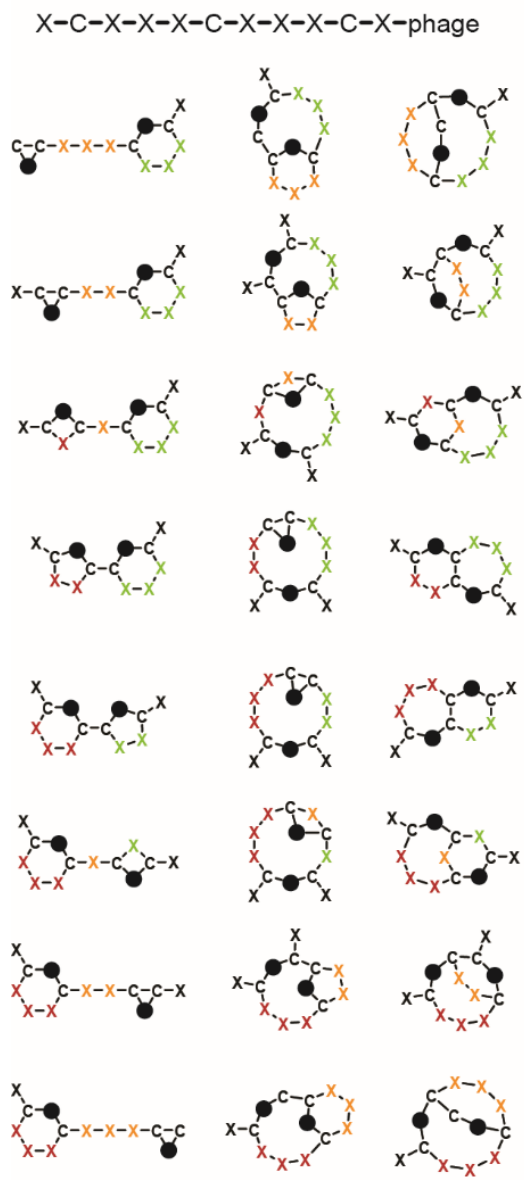

library 2

$x-c-x-x-x-x-c-x-x-x-x-c-x-$ phage
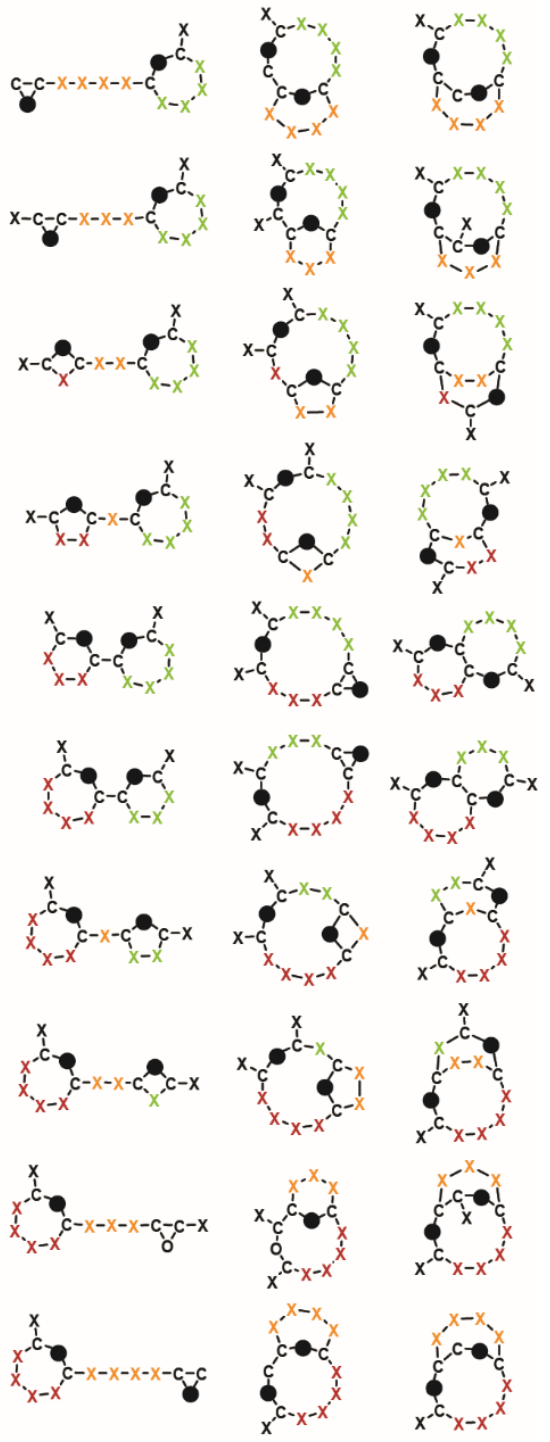

Supplementary Figure 2 Around 20\% of peptides in library $1\left(\mathrm{XCX}_{3} \mathrm{CX}_{3} \mathrm{CX}\right.$-phage) and $23 \%$ of peptides in library $2\left(\mathrm{XCX}_{4} \mathrm{CX}_{4} \mathrm{CX}\right.$-phage) contain an additional cysteine in one of the random positions indicated with ' $X$ '. Cyclization with a chemical linker (indicated as a black ball) yields the indicated scaffolds. Random amino acids in the three segments are shown in red, orange and green. 


\begin{tabular}{|c|c|c|c|c|c|c|}
\hline peptide format: & \multicolumn{6}{|c|}{$\%$ of peptides (among those having 4 cysteines) } \\
\hline linker: & 1 & 3 & 4 & 7 & 10 & 12 \\
\hline $\mathrm{c} c \times \times \times \mathrm{c} \times \times \times \times c \times$ & $7 \%$ & $8 \%$ & $2 \%$ & $2 \%$ & $4 \%$ & | $7 \%$ \\
\hline$x \operatorname{cox} \times \times c \times \times \times \times c \times$ & $16 \%$ & $20 \%$ & $11 \%$ & $11 \%$ & $18 \%$ & | $3 \%$ \\
\hline$\times c \times c \times x \times c \times x \times c \times$ & $\mid 1 \%$ & $2 \%$ & $2 \%$ & $1 \%$ & $2 \%$ & $2 \%$ \\
\hline$x c \times x c \times c \times x \times x c \times$ & $7 \%$ & | $5 \%$ & $29 \%$ & | $3 \%$ & | $5 \%$ & $2 \%$ \\
\hline$x \subset \times x \times c c \times x \times \times c \times$ & $22 \%$ & $9 \%$ & $28 \%$ & | $4 \%$ & $25 \%$ & | $3 \%$ \\
\hline$x \subset \times x \times x c c \times x \times c \times$ & | $4 \%$ & | $6 \%$ & | $4 \%$ & $19 \%$ & 】 $9 \%$ & | $2 \%$ \\
\hline$x c \times x \times x c \times c \times x c \times$ & $13 \%$ & | $3 \%$ & $14 \%$ & $11 \%$ & $8 \%$ & $2 \%$ \\
\hline$x c \times x \times \times c \times x c \times c \times$ & $6 \%$ & $2 \%$ & | $4 \%$ & $10 \%$ & | $6 \%$ & $1 \%$ \\
\hline$x \subset \times x \times \times c \times x \times c c \times$ & $7 \%$ & $12 \%$ & $2 \%$ & $15 \%$ & I $6 \%$ & $2 \%$ \\
\hline$\times c \times \times \times \times c \times \times \times \times c c$ & $17 \%$ & $34 \%$ & $4 \%$ & $24 \%$ & $16 \%$ & $76 \%$ \\
\hline
\end{tabular}

Supplementary Figure 3 Abundance of peptide formats after panning library 2 cyclized with the indicated linkers against plasma kallikrein. Abundance is indicated in \% of those peptides containing four cysteines. Abundance of peptide formats from library 1 is shown in Fig. 3a. 


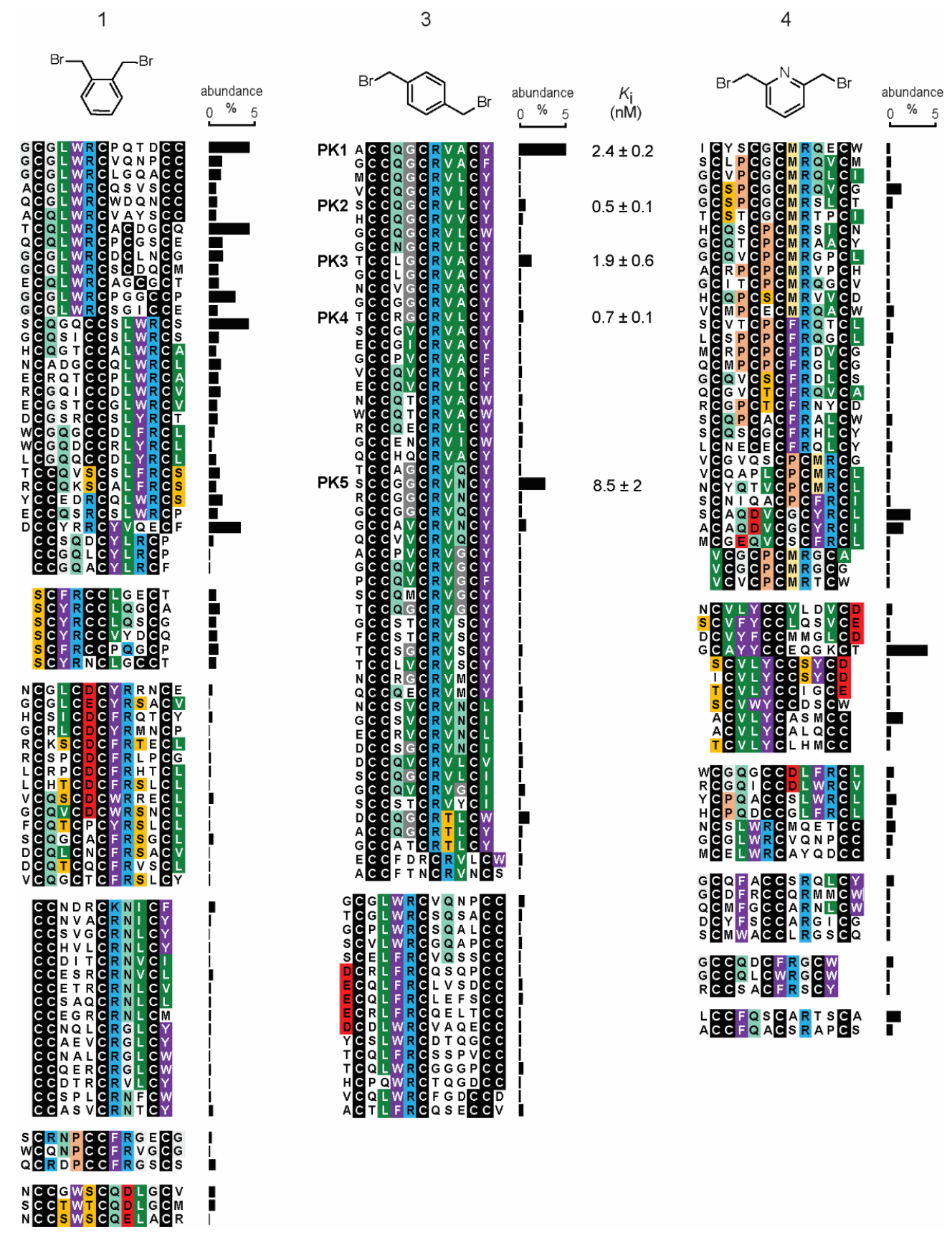

Supplementary Figure 4 Consensus sequences. Peptides isolated from libraries 1 and 2 cyclized with the chemical linkers 1, 3, 4, 7, 10, and 12 after two rounds of selection. Peptides with similar sequences are aligned in groups and amino acid similarities highlighted in color. Nine peptides were synthesized and characterized. The $K_{\mathrm{i}}$ of the most active isomer of each peptide is indicated. Standard deviations of at least three $K_{\mathrm{i}}$ measurements are shown. 


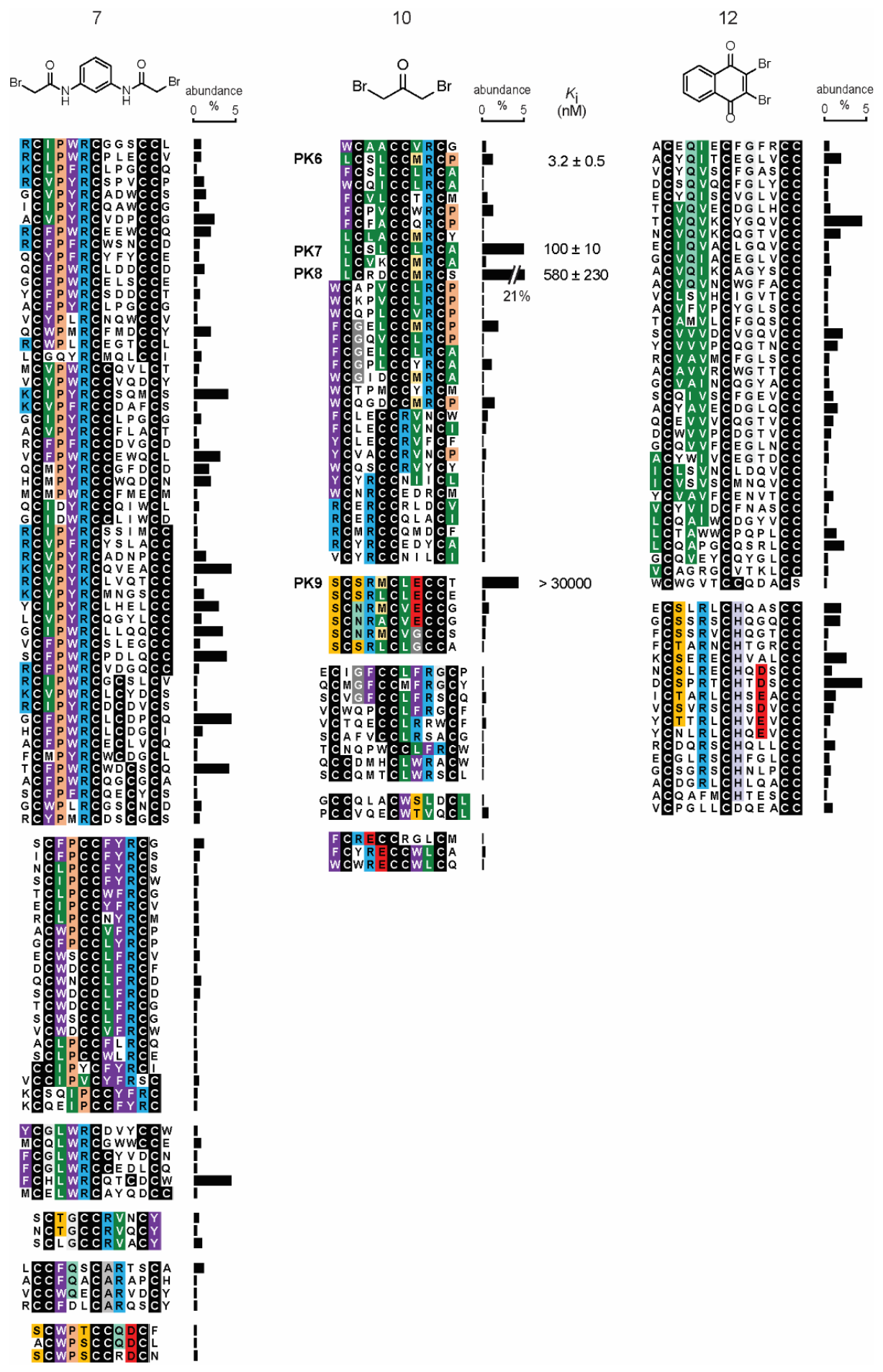

Supplementary Figure 4 Continued 

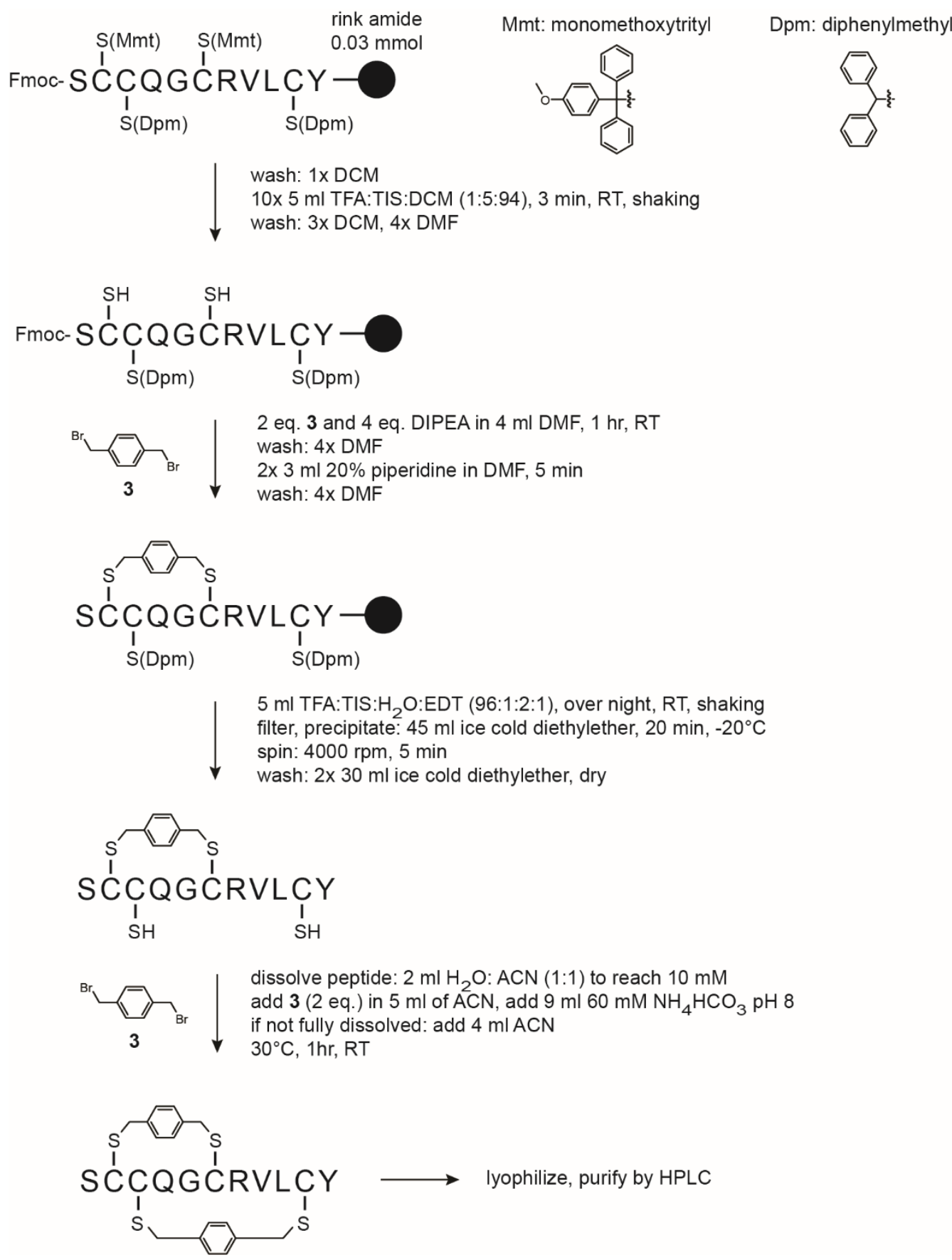

Supplementary Figure 5 Strategy for the synthesis of individual regioisomers of double-bridged peptides. The first pair of cysteines is reacted on resin and the second pair in solution. 

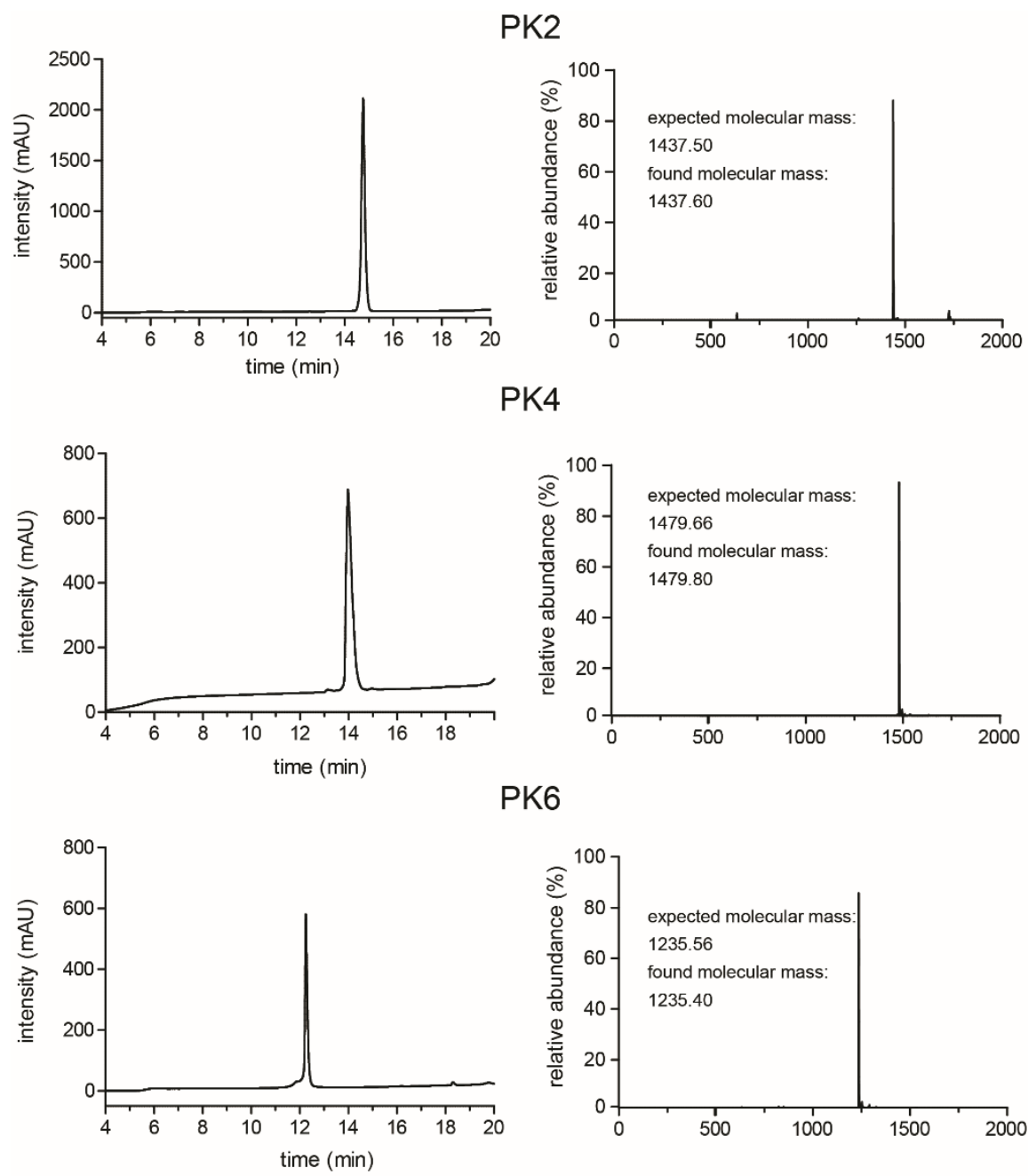

\section{PK10}
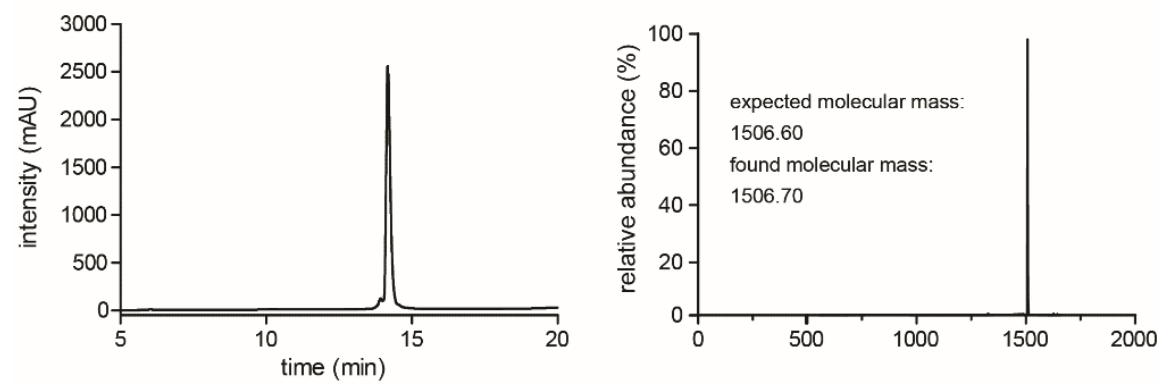

Supplementary Figure 6 Analytical RP-HPLC chromatograms of the plasma kallikrein inhibitors PK2 (isomer 3), PK4 (isomer 3), PK6 (isomer 1) and PK10 (isomer 3). Expected and measured molecular masses are indicated. 

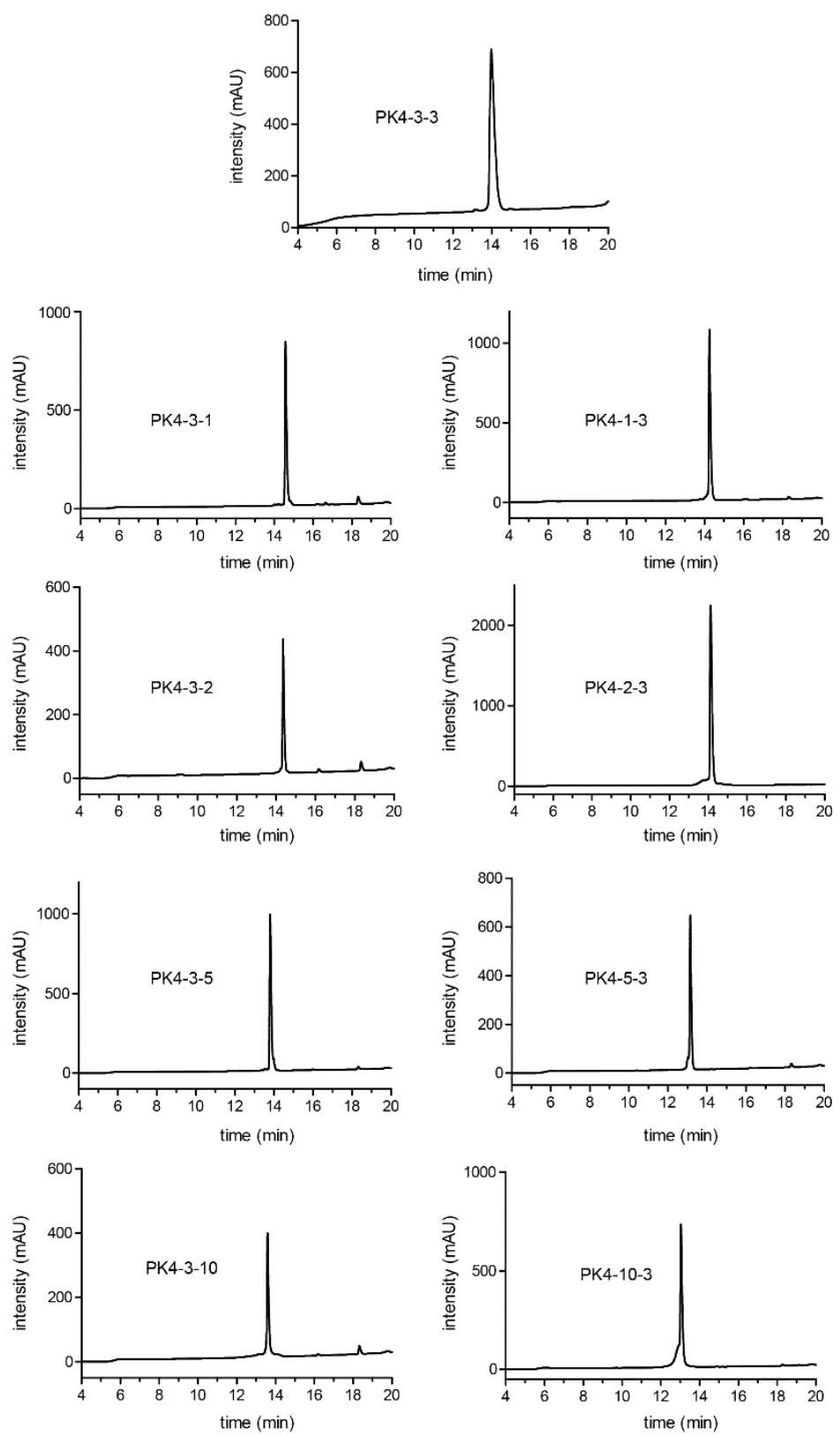

Supplementary Figure 7 Analytical RP-HPLC chromatograms of bicyclic peptide PK4 (isomer 3) in which one of the two linkers was exchanged. The two numbers following the name "PK4" indicate the first and second linker, respectively. 

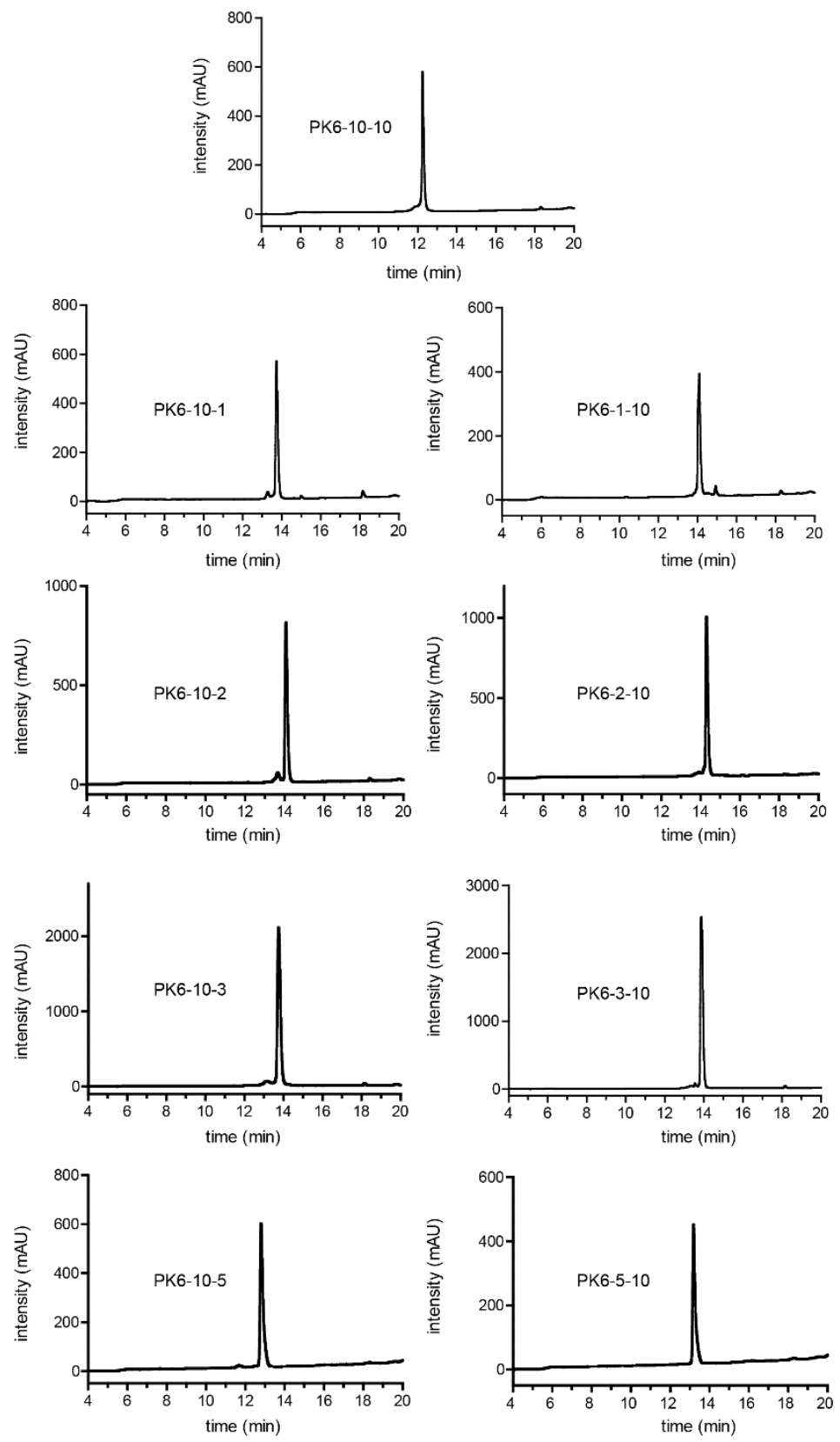

Supplementary Figure 8 Analytical RP-HPLC chromatograms of bicyclic peptide PK6 (isomer 1) in which one of the two linkers was exchanged. The two numbers following the name "PK6" indicate the first and second linker, respectively. 
a

PK4 (isomer 3)
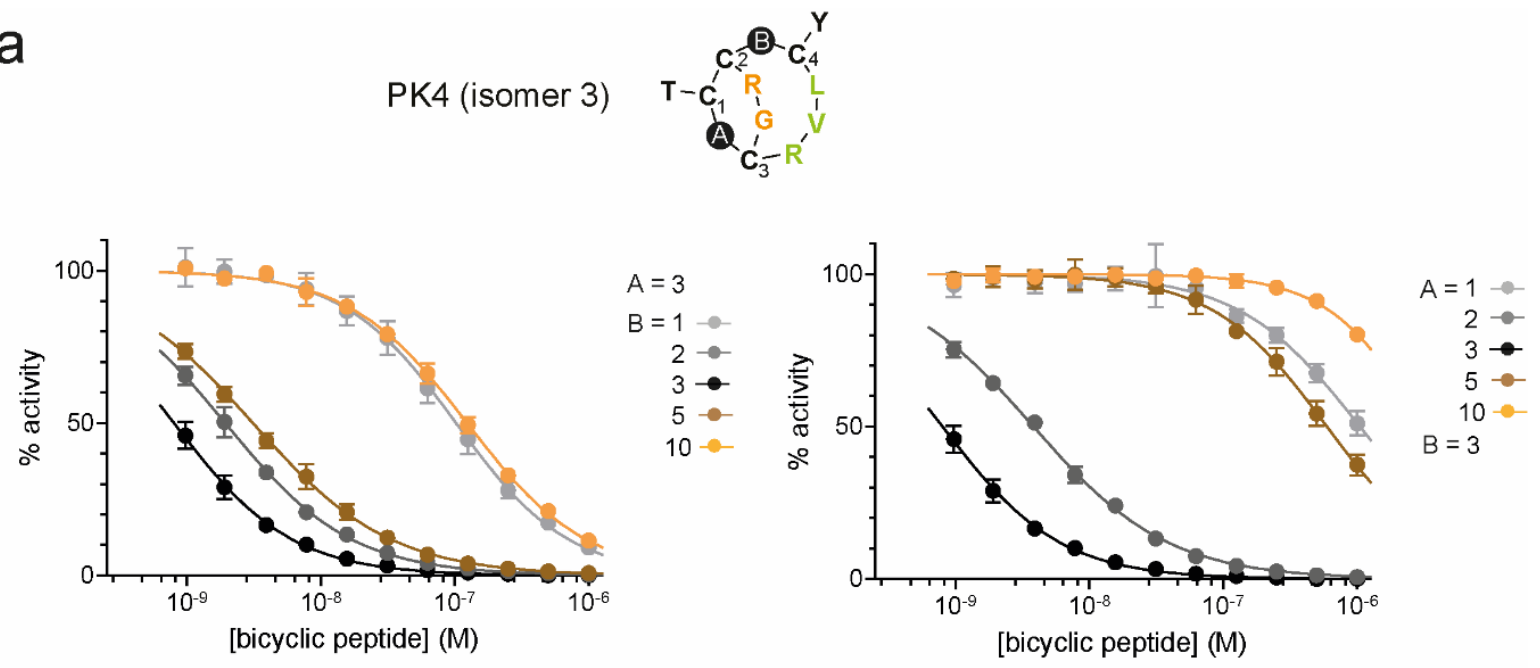

b

PK6 (isomer 1)

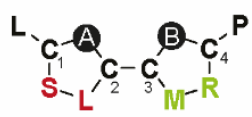
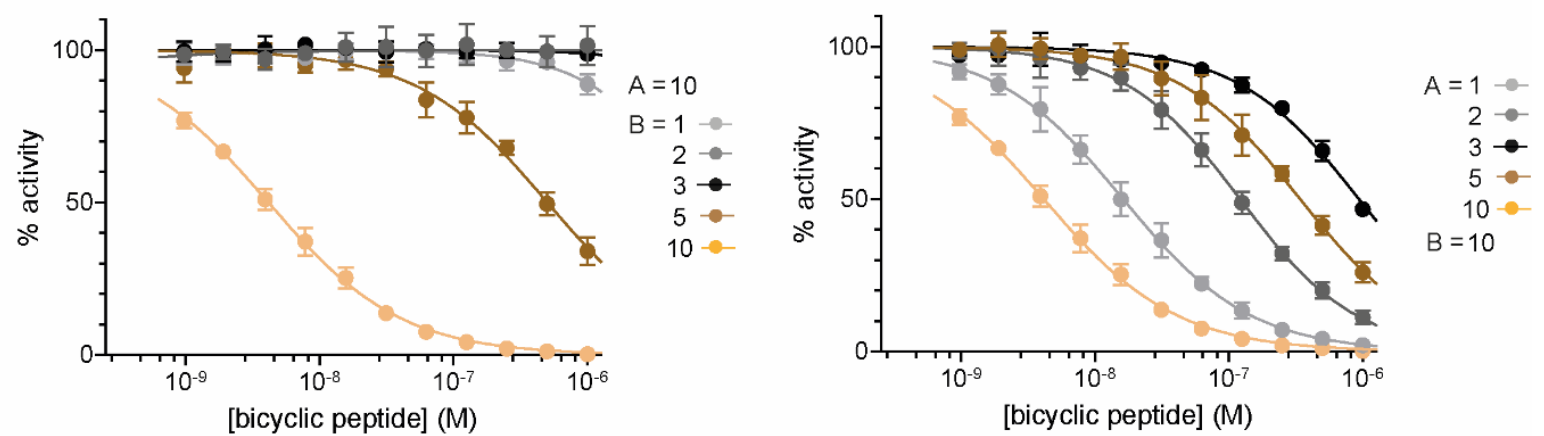

Supplementary Figure 9 Linker swapping. a, One of the two linkers of the bicyclic peptide PK4 (isomer 3) cyclized with linker $\mathbf{3}$ was replaced to either of five different linkers. b, One of the two linkers of the bicyclic peptide PK6 (isomer 1) cyclized with linker 3 was replaced to either of five different linkers. The residual activity of plasma kallikrein is shown. Values and standard deviations were calculated based on three measurements. 
a<smiles>Fc1c(F)c(F)c(CBr)c(CBr)c1F</smiles>

13<smiles>Cc1cc(CBr)c(C)cc1CBr</smiles>

16<smiles>Clc1cc(CBr)c(Cl)cc1CBr</smiles>

14<smiles>Cc1c(C)c(CBr)c(C)c(C)c1CBr</smiles>

17<smiles>BrCc1cc(Br)c(CBr)cc1Br</smiles>

15<smiles>COc1cc(CBr)c(OC)cc1CBr</smiles>

18<smiles>COC(=O)c1cc(CBr)c(C(=O)OC)cc1CBr</smiles>

19

b

PK2 (isomer 3)

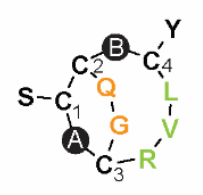

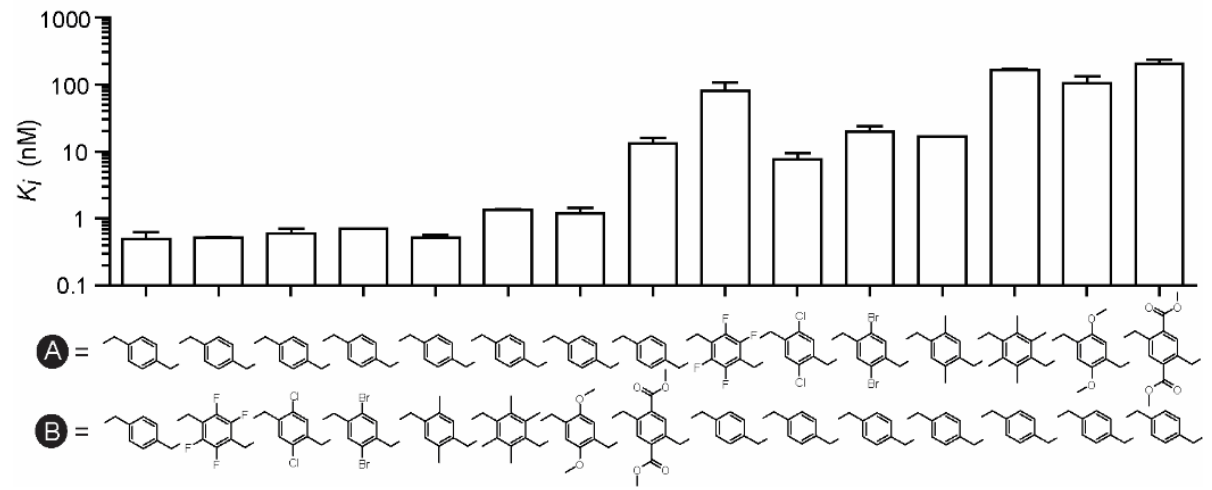

Supplementary Figure 10 Cyclization of peptides with linkers having similar structures. a, Chemical reagents resembling linker $\mathbf{3}$. $\mathbf{b}$, Inhibition of plasma kallikrein by bicyclic peptide PK2 (isomer 3) in which one of the two linkers was substituted. 

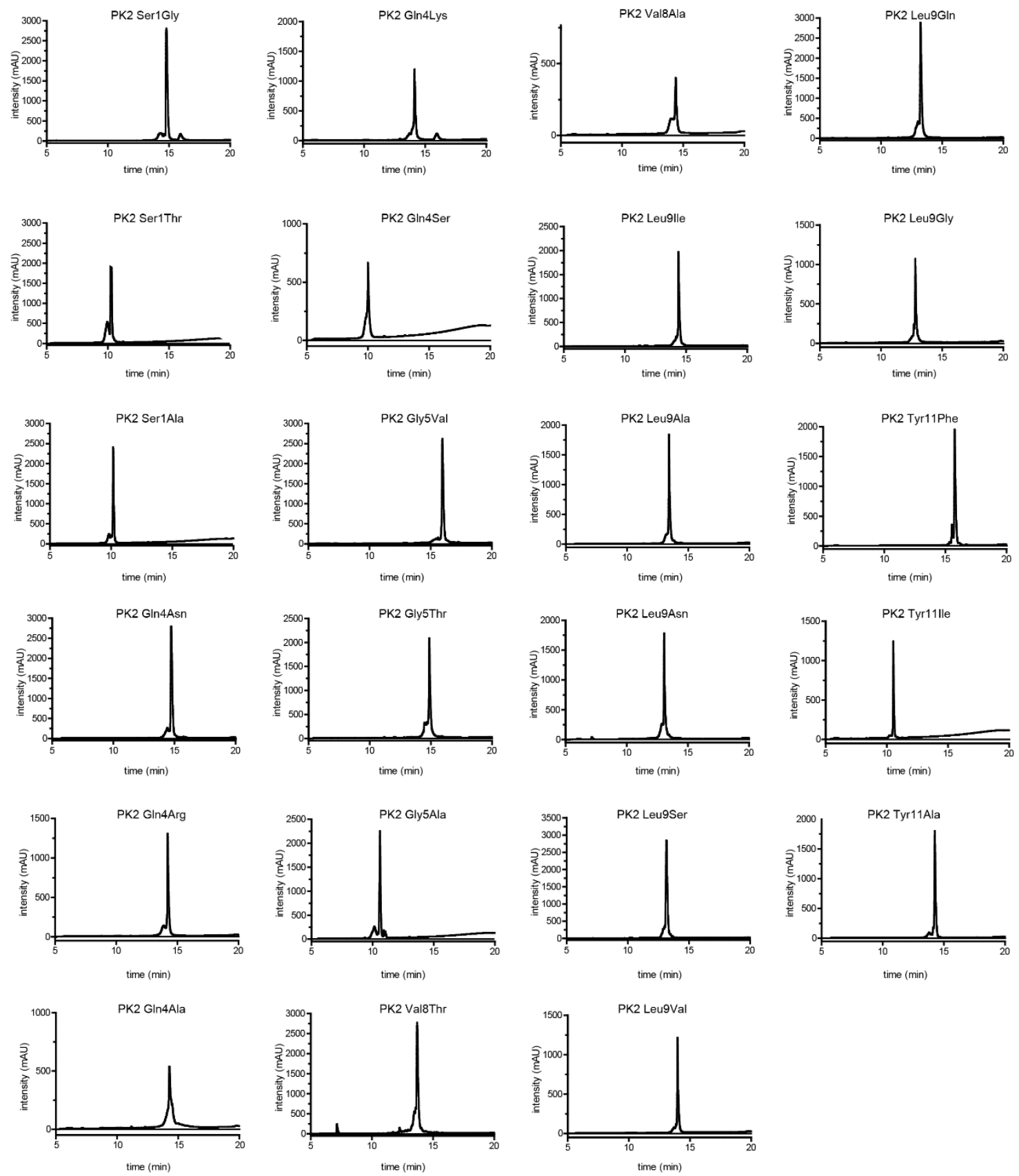

Supplementary Figure 11 Analytical RP-HPLC chromatograms of bicyclic peptide PK2 (isomer 3) variants in which one amino acid was substituted as indicated in the names. 


$\begin{array}{lll}\text { XCXXXCCCX } & \text { XCXXXXCCCX } & \text { XCXXXXXCCCX } \\ \text { XCXXCXCCX } & \text { XCXXXCXCCX } & \text { XCXXXXCXCCX } \\ \text { XCXCXXCX } & \text { XCXXCXXCCX } & \text { XCXXXXXCCX } \\ \text { XCCXXXCCX } & \text { XCXCXXXCCX } & \text { XCXXCXXXCXX } \\ \text { XCXXCCXCX } & \text { XCCXXXXCCX } & \text { XCXCXXXXCCX } \\ \text { XCXCXCXCX } & \text { XCXXXCCXCX } & \text { XCCXXXXXCCX } \\ \text { XCCXXCXCX } & \text { XCXXCXCXCX } & \text { XCXXXXCCXCX } \\ \text { XCXCCXXCX } & \text { XCXCXXCXCX } & \text { XCXXXCXCXCX } \\ \text { XCCXCXXCX } & \text { XCCXXXCXCX } & \text { XCXXCXXCXCX } \\ \text { XCCCXXXCX } & \text { XCXXCCXXCX } & \text { XCXCXXXCXCX } \\ & \text { XCXCXCXXCX } & \text { XCCXXXXCXCX } \\ & \text { XCCXXCXXCX } & \text { XCXXXCCXXCX } \\ & \text { XCXCCXXXCX } & \text { XCXXCXCXXCX } \\ & \text { XCCXCXXXCX } & \text { XCXCXXCXXCX } \\ & \text { XCCCXXXXCX } & \text { XCCXXXCXXCX } \\ & & \text { XCXXCCXXXCX } \\ & & \text { XCXCXCXXXCX } \\ & & \text { XCCXXCXXXCX } \\ & & \text { XCXCCXXXXCX } \\ & & \text { XCCXCXXXXCX } \\ & & \text { XCCCXXXXXCX }\end{array}$
codons.

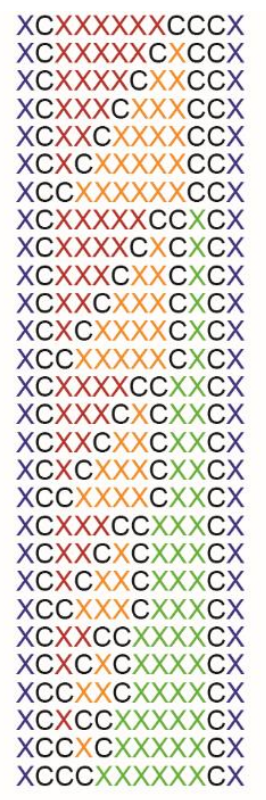

$X C X X X X X X X C C C X$ $X C X X X X X X C X C C X$ $X C X X X X X C X X C C X$ XCXXXXCXXXCCX $X C X C X X X X X X C C X$ $X C C X X X X X X X C C X$ XCXXXXXXCCXCX $X C X X X X X C X C X C X$ $X C X X X X C X X C X C X$ $X C X X X C X X X C X C X$ $X C X X C X X X X C X C X$ $X C X C X X X X X C X C X$ $X C C X X X X X X C X C X$ $X C X X X X X C C X X C X$ $X C X X X X C X C X X C X$ $X C X X X C X X C X X C X$ $X C X C X X X X C X X C X$
$X C X X C X X X C X X C X$ $X C C X X X X X C X X C X$ XCXXXXCCXXXCX $X C X X X C X C X X X C X$ $X C X X C X X C X X X C X$ $X C X C X X X C X X X C X$ $X C C X X X X C X X X C X$ $X C X X X C C X X X X C X$ $X C X X C X C X X X X C X$ $X C X C X X C X X X X C X$ $X C C X X X C X X X X C X$ XCXXCCXXXXXCX $X C X C X C X X X X X C X$ $X C C X X C X X X X X C X$ $X C X C C X X X X X X C X$ $X C C X C X X X X X X C X$ $X C C C X X X X X X X C X$

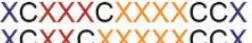

XCXXXXXXXXCCCX $X C X X X X X X X C X C C X$ $X C X X X X X X C X X C C X$ $X C X X X X X C X X X C C X$

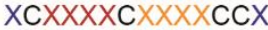
$X C X X X C X X X X X C C X$ $X C X X C X X X X X X C C X$ XCXCXXXXXXXCCX $X C C X X X X X X X X C C X$ $X C X X X X X X X C C X C X$ $X C X X X X X X C X C X C X$ XCXXXXXCXXCXCX XCXXXXCXXXCXCX $X C X X X C X X X X C X C X$ XCXXCXXXXXCXCX $X C X C X X X X X X C X C X$ XCCXXXXXXXCXCX $X C X X X X X X C C X X C X$ $X C X X X X X C \times C X X C X$ $X C X X X X C X X C X X C X$ $X C X X X C X X X C X X C X$ XCXXCXXXXCXXCX XCCXXXXXXCXXCX $X C X X X X X C C X X X C X$ XCXXXXCXCXXXCX $X C X X X C X X C X X X C X$ $X C X X C X X X C X X X C X$ $X C X C X X X X C X X X C X$ $X C C X X X X X C X X X C X$ XCXXXXCCXXXXCX $X C X X X C X C X X X X C X$ $X C X X C X X C X X X X C X$ $X C X C X X X C X X X X C X$ $X C C X X X X C X X X X C X$ $X C X X X C C X X X X X C X$ $X C X X C X C X X X X X C X$ $X C X C X \times C X X X X X C X$ XCCXXXCXXXXXCX XCXXCCXXXXXXCX XCXCXCXXXXXXCX $\mathrm{XCC} X X \mathrm{C} X X X X X X \mathrm{CX}$ $X C X C C X X X X X X X C X$ $X C C X C X X X X X X X C X$ $X C C C X X X X X X X X C X$ $X C X C X X X X X C X X C X$

\section{Supplementary Figure 12 Peptide formats in phage display library 3. The peptides have lengths \\ between 9 and 14 amino acids and contain cysteines in four fixed positions. The library was cloned
using 155 degenerate DNA primers in which the random amino acids were encoded by NNK \\ between 9 and 14 amino acids and contain cysteines in four fixed positions. The library was cloned
using 155 degenerate DNA primers in which the random amino acids were encoded by NNK}



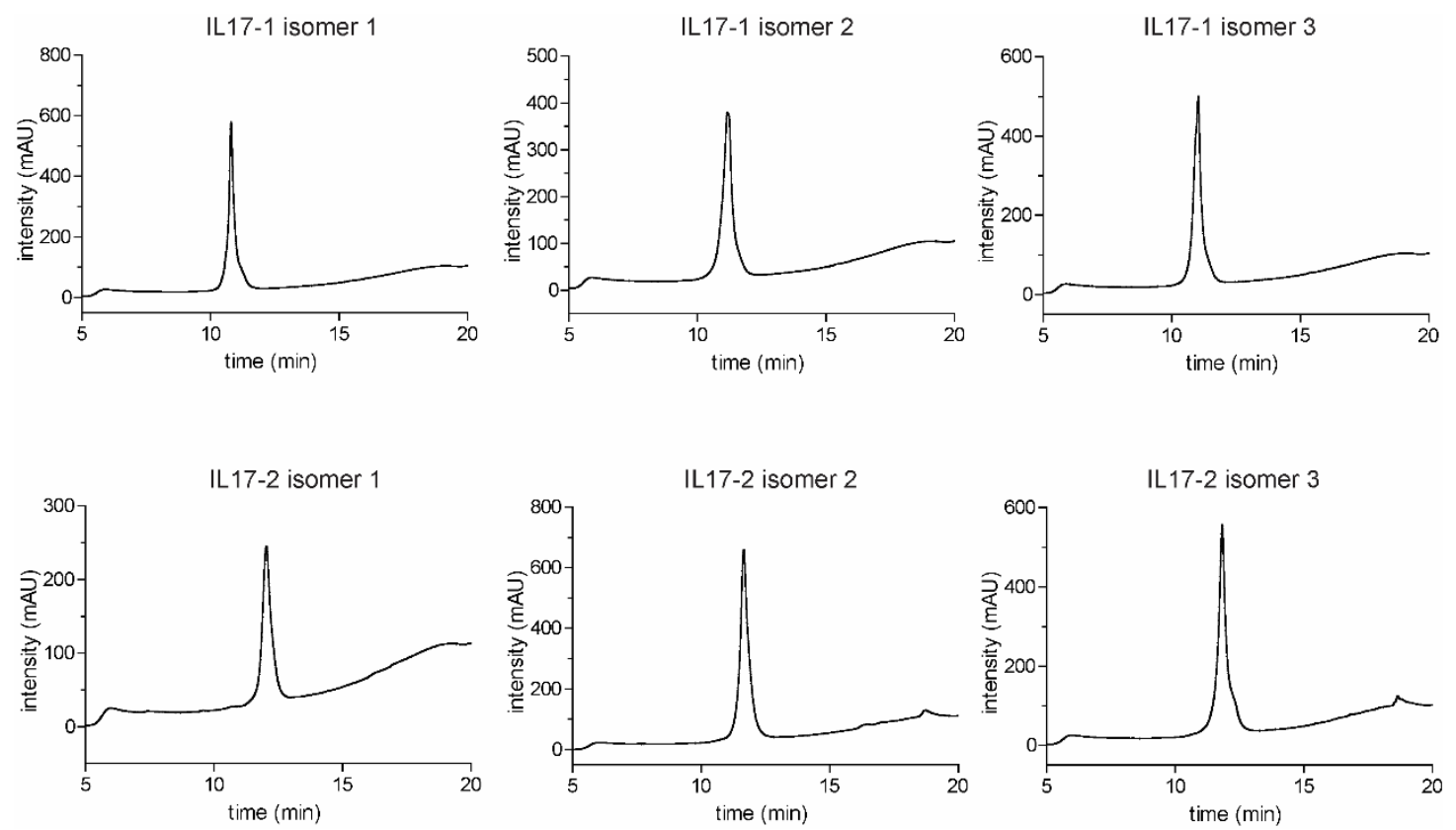

Supplementary Figure 13 Analytical RP-HPLC chromatograms of bicyclic peptide ligands of IL17. 